\title{
The influence of heavy metals on biological soil quality assessments in the Vaccinium myrtillus L. rhizosphere under different field conditions
}

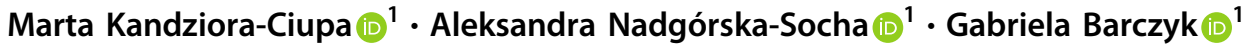

Accepted: 5 January 2021 / Published online: 26 January 2021

(c) The Author(s) 2021

\begin{abstract}
The aim of this study was to determine the influence of heavy metals on biological soil quality assessments in Vaccinium myrtillus L. rhizosphere soil as well as in non-rhizosphere soil from different polluted sites. The presented study was also conducted in order to determine any differences in the soil physicochemical and biological properties between the Vaccinium rhizosphere soil and the non-rhizosphere soil. The content of heavy metals and their potential bioavailability, content of macronutrients, physicochemical soil properties, activity of six soil enzymes and microarthropod communities were determined. Soil organic matter, the levels of $C, N$ and all the studied macronutrients and almost all enzyme activity were significantly higher in the rhizosphere soil than in the nonrhizosphere soil. At the most contaminated site, the content of heavy metals was also higher in the rhizosphere soil, but their bioavailability was lower than in the non-rhizosphere soil. The $\beta$-glucosidase and urease activity in the soil correlated most negatively with the examined metals. The levels of two enzymes were also strongly impacted by the organic matter-the $C$ and $N$ levels and $\mathrm{pH}$. The number of microarthropods as well as the QBS (soil biological quality index) and $F_{\text {EMI }}$ (abundance-based fauna index) were higher in the rhizosphere soil. The bilberry rhizosphere soil had stronger correlation coefficient values between the measured parameters than the non-rhizosphere soil, which suggests that rhizosphere soil is more sensitive and could be used in the monitoring and assessment of forest ecosystems. $\beta$-glucosidase and urease were the most sensitive indicators of the adverse impact of $\mathrm{Cd}, \mathrm{Zn}$ and $\mathrm{Pb}$. The $F_{\mathrm{EMI}}$ index seems to be a better indicator than the QBS for identifying differences in soil quality.
\end{abstract}

Keywords Bilberry $\cdot$ Forest soils $\cdot$ Soil pollution $\cdot$ Soil quality $\cdot$ Root zone

Abbreviations

AS arylsulphatase

$\beta \mathrm{G} \quad \beta$-glucosidase

Deh dehydrogenase

AlP alkaline phosphatase

AP acid phosphatase

Ure urease

PLI pollution load index

TEI total enzyme activity index

$M_{w} \quad$ potential biochemical soil fertility index

ACR enzyme activity change ratio

Marta Kandziora-Ciupa

marta.kandziora-ciupa@us.edu.pl

1 Faculty of Natural Sciences, Ecology, Institute of Biology, Biotechnology and Environmental Protection, University of Silesia in Katowice, Bankowa 9, 40-007 Katowice, Poland
QBS soil biological quality index

FEMI abundance-based fauna index

\section{Introduction}

Soils are often a sink for pollutants especially for heavy metals in anthropogenic environments (Jiao et al. 2015; Navarrete et al. 2017). Heavy metals in soils, which are characterized by a high stability in the environment and are generally not biodegradable, can be released from terrestrial environments into other ecosystem compartments such as groundwater, rivers, atmosphere and other (Mmolawa et al. 2011; Mazurek et al. 2017). They can reach hazardous levels to human beings, hence, the need for constant monitoring and regulation of their concentrations in the soil (Karaca et al. 2010; Jia et al. 2018). Soil physicochemical properties are not suitable for estimating changes in environmental pollution because they change very 
slowly and can only be detected after many years. Therefore, any research on pollution-induced changes in soil quality must be based on the properties that respond rapidly to minor changes in environmental stress (Trasar-Cepeda et al. 2008; Tan et al. 2014). One of the suggested biological indicators is soil enzyme activity level, which rapidly responds to any ecosystem variation and changes in the soil, including those that are induced by heavy metals. Because it is easily measured, it could provide a useful tool for environmental monitoring (Rao et al. 2014). In addition, understanding the effects of heavy metals on soil enzyme activity may also provide an opportunity for an integrated assessment of soil biology (Yang et al. 2017). Increased contents of heavy metals in soil above a certain threshold generally adversely affect the growth, morphology, and metabolism of microorganisms, which leads to a decrease in the functional diversity of soil ecosystems (Hassan et al. 2013). They can inhibit soil enzyme activity by interacting with enzyme active sites and substrate complexes and denaturing the enzyme protein (Vig et al. 2003; Yang et al. 2017). Soil organisms are also useful in monitoring environmental changes because they provide objective metrics that integrate physical, chemical, and biological parameters (Blakely et al. 2002; Galli et al. 2014). For example, microarthropods are widely seen as bioindicators (Stork and Eggleton 1992; Paoletti 1999) and are used in the indexes of soil quality in environmental monitoring (Yan et al. 2011). Parissi et al. (2005) and Parisi and Menta (2008) proposed a simplified eco-morphological index (EMI) that is based on the types of soil microarthropods that are present and this index was used to evaluate soil quality by generating another index - the QBS (soil biological quality) (Yan et al. 2011). The QBS index is based on the concept that at a higher soil quality, the number of microarthropod groups that are well adapted to soil habitats will be higher (Parissi et al. 2005).

From the viewpoint of microbial ecology, the rhizosphere is a special unique hot spot in the soil where microorganisms are considerably stimulated by the activity of the roots (Jones et al. 2004; Hisinger et al. 2006; Egamberdieva et al. 2011). The rhizosphere is also an important site of material cycling and energy flow (Xiao et al. 2017) and has a significant influence on the availability or solubility of nutrients as well as on the availability of heavy metals (Orroño et al. 2012). Because of this, the distribution of heavy metals in rhizosphere soil is more significant for the evaluation of the bioavailability of heavy metals than bulk soil is (Youssef 1997).

Vaccinium myrtillus L. (bilberry) is the most frequent and abundant dwarf shrub species in the understory of the conifer forests in Europe and Northern Asia. As a species, it has special significance for the development of pine and mixed oak-pine forests undergrowth structure and is a species that is particularly important for the regeneration of post-agricultural forest communities. Bilberry makes a significant contribution to the soil processes in this community type because it is a major contributor to the formation and accumulation of the humus layer and in the prevention of soil erosion (Matuszkiewicz et al. 2013; Liu et al. 2014; Kandziora-Ciupa et al. 2017). However, information about the rhizosphere effect of Vaccinium myrtillus L. on soil properties, activities soil enzymes and microarthropod abundance, especially in heavy-metal contaminated soils, is still unknown. Therefore, the objectives of this study were to (1) evaluate the differences in the rhizosphere and non-rhizosphere soil properties from different contaminated stands; (2) assess the influence of heavy metal pollution on the enzyme activity in rhizosphere and non-rhizosphere soils; (3) compare the biological indicators of soil quality (QBS and $F_{\mathrm{EMI}}$ ) based on the microarthropod numbers in rhizosphere and non-rhizosphere soils. We postulate that the results of this study will contribute essential information for the monitoring and assessment of forests soils and will provide a better understanding of the processes that occur in rhizosphere soil that is under heavy metal contamination.

\section{Material and methods}

\section{Study area}

The study was performed in a middle-aged (60-80 years old) Scots pine forest, which is mixed with birch (Betula pendula L.), European beech (Fagus sylvatica L.) and pedunculate oak (Quercus robur L.) that are growing on sandy acidic soils that are located at three differently polluted sites (the immediate vicinity of the "Miasteczko Śląskie" zinc smelter (M), of the mining and metallurgical plant in Bukowno (B) and a main road with high trafficKatowice-Kostuchna $(\mathrm{K})$ ) as well as in an unprotected natural forest community in Kokotek (KO) (Fig. 1). The dominant species in understory of all research areas was Vaccinium myrtillus L. (coverage in all sampling sites was $50-60 \%$ ). All the sites are located in the Ślaskie or Małopolskie provinces in southern Poland (in the SilesianKrakow highlands) and all sampling sites were homogeneous in terms of altitude and exposure. The research areas are flat land located at an altitude of 200-314 m above sea level (Table 1).

\section{Sample collection}

Soil samples were collected in May and September 2017 (Pennesi and Insom 2012). At each sampling site, ten randomly selected shrubs of Vaccinium myrtillus L. were carefully dug up from the field. The soil that was strongly adhering to the bilberry roots, which was separated by gently shaking by hand, was considered to be the 


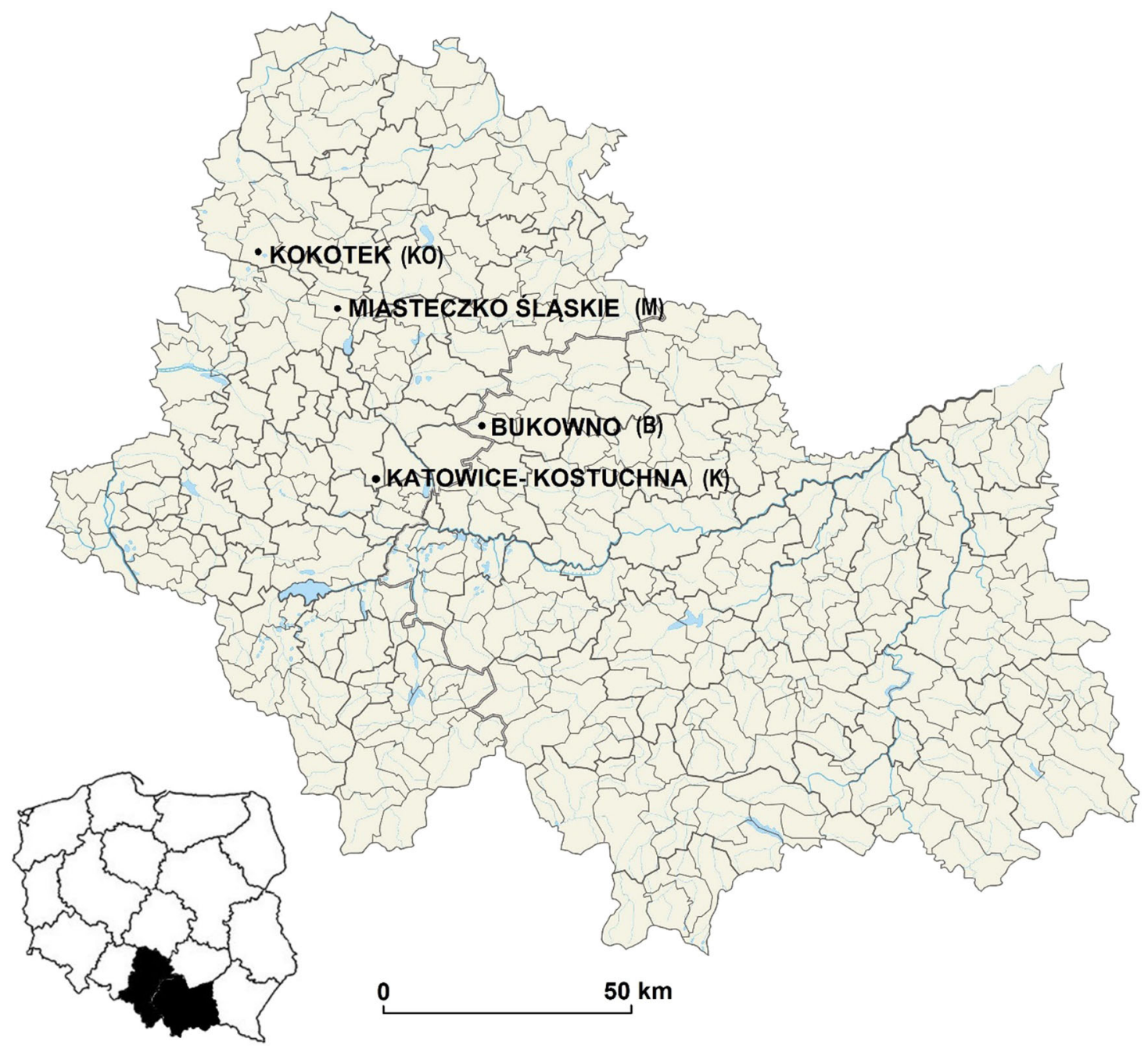

Fig. 1 Location map of sampling sites

rhizosphere soil (R) (Baudoin et al. 2002; Garcia et al. 2005; Ge et al. 2011). Ten samples were also collected from areas without vegetation or with light vegetation but without $V$. myrtillus (distances of at least $50 \mathrm{~cm}$ from the rhizosphere of individual plants in order to avoid the influence of rhizosphere) - for the sake of simplicity and for the needs of this article, we will call this soil "non-rhizosphere" soil (NR). At each study site, ten soil samples of each type of soil (separately rhizosphere and non-rhizosphere) that had been collected from all of the sampling sites were combined into three composite samples and then divided into two subsamples: one subsample was used to determine the heavy metal content, the second was used for the physicochemical analysis and the third for the enzyme activity analysis. All the measurements were done in triplicate.

At each sampling site, soil samples were additionally collected for the study of the microarthropod community. A total of 48 soil samples $(10 \mathrm{~cm} \times 10 \mathrm{~cm} \times 10 \mathrm{~cm})$-rhizosphere (24) and non-rhizosphere (24) was collected. The fauna was extracted over seven days using a Berlese-Tullgren funnel. The arthropods were preserved in $75 \%$ ethanol. The extracted specimens were counted under a stereo microscope at a low magnification and identified to the order level.

\section{Soil properties}

Soil $\mathrm{pH}$ was measured using a 1:2.5 soil to water ratio. The organic matter content (\%) was determined using the losson-ignition (LOI) method by heating $5.0 \mathrm{~g}$ of soil at $550{ }^{\circ} \mathrm{C}$ for seven hours following the method of Ostrowska et al. (1991).

The soil concentration of heavy metals $(\mathrm{Cd}, \mathrm{Mn}, \mathrm{Zn}, \mathrm{Fe}$, $\mathrm{Pb})$ and macronutrients $(\mathrm{K}, \mathrm{Mg}, \mathrm{Na}, \mathrm{Ca}, \mathrm{P}, \mathrm{S})$ were estimated in air-dried soil samples that had been sieved through a $2 \mathrm{~mm}$ sieve according to Zheljazkov et al. (2008) and Wójcik et al. (2014). The metals and macronutrients were extracted from the samples with concentrated $\mathrm{HNO}_{3}(65 \%)$ 
Table 1 Study sites

\begin{tabular}{|c|c|c|c|}
\hline \multirow[t]{2}{*}{ Abbreviation } & \multirow[t]{2}{*}{ Sites } & \multicolumn{2}{|l|}{ GPS } \\
\hline & & Latitude & Longitude \\
\hline M & $\begin{array}{l}\text { Nearest vicinity of zinc smelter "Miasteczko Śląskie" in Miasteczko Śląskie (activities } \\
\text { since 1968) }\end{array}$ & $50^{\circ} 31^{\prime} 22.655^{\prime \prime} \mathrm{N}$ & $18^{\circ} 56^{\prime} 8.699^{\prime \prime} \mathrm{E}$ \\
\hline B & $\begin{array}{l}\text { The nearest vicinity of ZGH "Boleslaw" Mining and Metallurgical Plant in Bukowno } \\
\text { (activities since 1955) }\end{array}$ & $50^{\circ} 15^{\prime} 55.6^{\prime \prime} \mathrm{N}$ & $19^{\circ} 26^{\prime} 34.64^{\prime \prime} \mathrm{E}$ \\
\hline K & Katowice-Kostuchna province. vicinity of the main road. with high traffic & $50^{\circ} 11^{\prime} 42.75^{\prime \prime} \mathrm{N}$ & $19^{\circ} 0^{\prime} 26.363^{\prime \prime} \mathrm{E}$ \\
\hline $\mathrm{KO}$ & Unprotected natural forest community in Kokotek-province of Lubliniec (control site) & $50^{\circ} 36^{\prime} 21.287^{\prime \prime} \mathrm{N}$ & $18^{\circ} 42^{\prime} 59.806^{\prime \prime} \mathrm{E}$ \\
\hline
\end{tabular}

(acid extracted elements) or with $0.01 \mathrm{M} \mathrm{CaCl}_{2}$ (potentially bioavailable elements - only metals). For the $\mathrm{HNO}_{3^{-}}$ extractable fraction, the soil samples $(0.5 \mathrm{~g})$ were placed in digestion tubes, soaked overnight in $5 \mathrm{ml}$ of concentrated $\mathrm{HNO}_{3}$ at room temperature, then decomposed further on an aluminum digestion block at $150{ }^{\circ} \mathrm{C}$ for $8 \mathrm{~h}$, filtered and diluted to $25 \mathrm{ml}$ with deionized water. For the $\mathrm{CaCl}_{2}$ extraction, $5 \mathrm{~g}$ of soil with a $50 \mathrm{ml} 0.01 \mathrm{M} \mathrm{CaCl}_{2}$ solution was mechanically shaken for $2 \mathrm{~h}$ at room temperature. The levels of the metals were measured in the filtered extracts using inductively coupled plasma-atomic emission spectroscopy (Spectro Analytical Instruments).

Total carbon, total nitrogen and the $C / N$ ratio were measured in an Elementar Vario MAX CNS Analyzer.

\section{Assessment of heavy metal pollution}

The single contamination factor $(\mathrm{CF})$ was used to assess the degree of pollution for each investigated metal:

$\mathrm{CF}=C_{s} / C_{c}$

where $C_{s}(\mathrm{mg} / \mathrm{kg})$ is the average concentration of elements in the samples and $C_{c}(\mathrm{mg} / \mathrm{kg})$ is the average concentration of the elements in the standards or control or an unpolluted area (Boamponsem et al. 2010; Yang et al. 2016; Fang et al. 2017). The contamination levels ranged from 1 to $6(0=$ none, $1=$ none to moderate, $2=$ moderate, $3=$ moderate to strong, $4=$ strongly polluted, $5=$ strong to very strong and 6 = very strong) (Muller, 1969).

To calculate the overall level of soil pollution across the sampling sites, the pollution load index (PLI) was determined (Bhuiyan et al. 2010, Yang et al. 2016; Fang et al. 2017):

$\mathrm{PLI}=\left(C_{f 1} \times C_{f 2} \times C_{f 3} \times \ldots \times C_{f n}\right)^{1 / n}$

where $C_{f}$ is the metal contamination factor and $n$ is the number of samples that were analyzed in this study. Four pollution levels were defined: no pollution $(\mathrm{PLI}<1)$, moderate pollution $(1<\mathrm{PLI}<2)$, heavy pollution $(2<\mathrm{PLI}<3)$ and extremely heavy pollution $(\mathrm{PLI}>3)$
(Liu et al. 2013; Yang et al. 2016; Fang et al. 2017). The PLI for each site's overall pollution level was also calculated (Table 5).

\section{Soil enzyme activity}

The activity of six enzymes (arylsulfatase (AS), $\beta$-glucosidase $(\beta \mathrm{G})$, dehydrogenase (Deh), alkaline (AlP), acid (AP) phosphatase and urease (Ure)) were determined. Fresh soil samples (rhizosphere and non-rhizosphere) from all four sites were sieved through a $2-\mathrm{mm}$ sieve and stored in plastic zip bags at $4{ }^{\circ} \mathrm{C}$. The substrate, incubation time, unit, and references of all the enzyme activities that were measured are listed in Table 2.

To assess the total level of soil enzyme activity, the TEI (total enzyme activity index) was calculated:

$\mathrm{TEI}=\sum \frac{X_{i}}{X_{l}}$

where $X_{i}$ is the activity of soil enzyme $i$ and $\overline{X_{i}}$ is the mean activity of enzyme $i$ in all the samples (Tan et al. 2014; Fang et al. 2017).

The potential biochemical soil fertility index $\left(M_{w}\right)$, which is based on the enzymatic activity and carbon content (Wyszkowska and Wyszkowski 2003), were calculated as follows:

$\mathrm{M}_{\mathrm{w}}=\left(\mathrm{Ure} 10^{-1}+\mathrm{Deh}+\mathrm{AlP}+\mathrm{AP}\right) \% \mathrm{C}$

where Ure is urease activity, Deh is dehydrogenase activity, AlP is alkaline phosphatase activity and AP is acid phosphatase activity.

To compare the effects of the heavy metals between the contaminated soils, the enzyme activity change ratio (ACR) was calculated (Xian et al. 2015; Gucwa-Przepióra et al. 2016):

$\mathrm{ACR}=\left(A_{h}-A_{c}\right) / A_{c} \times 100 \%$

where $A_{h}$ and $A_{c}$ are the enzyme activity of polluted (M, B and $\mathrm{K}$ ) and control (KO) soils, respectively. 


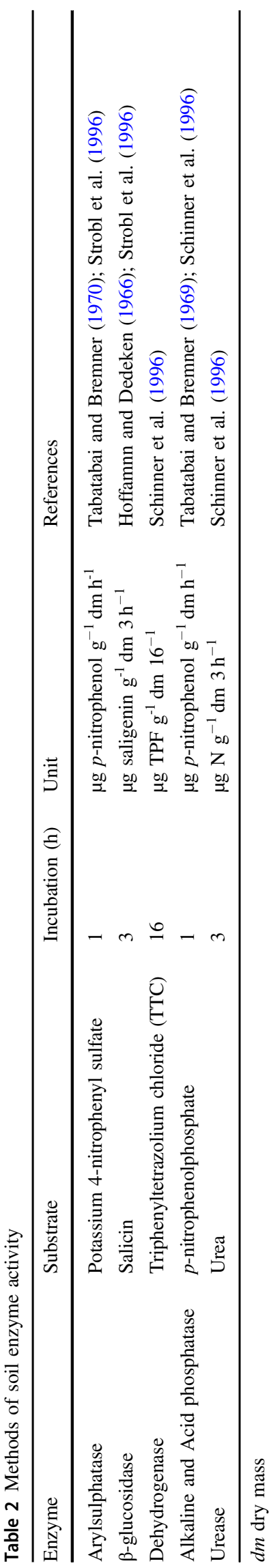

\section{Biological indices}

The soil biological quality index (QBS) was evaluated as reported by Parissi et al. (2005). The QBS considers the soil microarthropods, which are invertebrates that belong to the microarthropoda phylum that range in size between 0.2 and $2 \mathrm{~mm}$ (mesofauna). This QBS index classifies soil microarthropods based on their morphological characteristics, assigning each to a microarthropod group by different weights, which are represented by a different score, thereby defining the Ecomorphological indices (EMI) and the microarthropod groups presented in Parissi et al. (2005). The QBS is calculated as the sum of the EMI values in each soil type (Menta et al. 2018).

Soil quality was also estimated using the abundancebased (number of individuals) fauna index $\left(F_{\mathrm{EMI}}\right)$, which is based on the ecomorphological indices (EMI). This indicator, which was proposed by Yan et al. (2012), is based on the presence/absence of microarthropod groups and the abundance of individuals in those groups.

$F_{E M I}=\frac{S_{0}}{S} \times \frac{\sum_{i=1}^{S_{0}}\left(\frac{d_{i 0}}{d_{\text {imax }}} \times E M I_{i}\right)}{\sum_{i=1}^{S}\left(E M I_{i}\right)}$

where $S$ is the number of microarthropod groups at all of the sites in the study region $S_{0}$ is the number of microarthropod groups at one site in the study regiond $i_{0}$ is the abundance of microarthropod group $i d i_{\max }$ is the maximum abundance of microarthropod group $i$ in all of the sites in the study area and $E M I_{i}$ is the ecomorphological index of microarthropod group $i$.

Keys used to the taxonomical identification: Identification key (a): https://www.zoology.ubc.ca/ srivast/mites/index. html; ver.1.0 Identification key (b): https://keyserver. lucidcentral.org/key-server/player.jsp?keyId=56 and Insom, La Terza (2012).

\section{Statistical analysis}

The data concerning enzyme activity, metal content and other soil properties were checked for the normality and homogeneity of variance. When there was a normal distribution and variance homogeneity, the data was analyzed by ANOVA and the treatments were treated as the independent variables. Significant statistical differences of all of the variables were established using the Tukey's test (ANOVA; Statistica 10 package). The heat maps, which are based on Pearson's correlation coefficients and show the correlation between enzyme activity and soil characteristics, were generated using HEMI software (Heat Map Illustration, Version 1.0) (Deng et al. 2014). CANOCO 4.5 was used to perform the Principal Component Analysis, which assessed the similarities and relationships between the soil 
Table 3 The physicochemical properties of soil samples (mean values $\pm \mathrm{SD}, n=3$ )

\begin{tabular}{|c|c|c|c|c|c|c|c|}
\hline & & & $\mathrm{pH}$ & OM \% & $C \%$ & $N \%$ & $C / N$ \\
\hline \multirow[t]{4}{*}{ M } & V & $\mathrm{R}$ & $5.4 \pm 0.01 \mathrm{a}^{*}$ & $17.8 \pm 2.0 a^{*}$ & $9.58 \pm 1.07 \mathrm{a}^{*}$ & $0.50 \pm 0.05 \mathrm{a}^{*}$ & $19.26 \pm 0.26 \mathrm{a}^{*}$ \\
\hline & & NR & $4.7 \pm 0.05 \mathrm{a}^{\wedge}$ & $11.4 \pm 0.20 \mathrm{a}^{\wedge}$ & $5.56 \pm 0.20 \mathrm{a}^{\wedge}$ & $0.26 \pm 0.01 \mathrm{a}^{\wedge}$ & $21.48 \pm 0.09 \mathrm{a}^{\wedge}$ \\
\hline & IX & $\mathrm{R}$ & $5.1 \pm 0.02 \mathrm{a}^{*}$ & $17.5 \pm 0.90 \mathrm{a}^{*}$ & $8.16 \pm 0.00 \mathrm{a}^{*}$ & $0.40 \pm 0.01 \mathrm{a} *$ & $20.35 \pm 0.33 a^{*}$ \\
\hline & & NR & $4.6 \pm 0.01 \mathrm{a}^{\wedge}$ & $6.6 \pm 1.0 \mathrm{a}^{\wedge}$ & $3.99 \pm 0.42 \mathrm{a}^{\wedge}$ & $0.19 \pm 0.03^{\wedge}$ & $20.94 \pm 1.18 \mathrm{a}^{\wedge}$ \\
\hline \multirow[t]{4}{*}{ B } & V & $\mathrm{R}$ & $4.4 \pm 0.02 b^{*}$ & $49.4 \pm 0.40 c^{*}$ & $22.68 \pm 0.54 b^{*}$ & $0.80 \pm 0.02 b^{*}$ & $28.28 \pm 0.05 c^{*}$ \\
\hline & & NR & $5.0 \pm 0.02 b^{\wedge}$ & $23.9 \pm 0.90 \mathrm{c}^{\wedge}$ & $9.62 \pm 1.96 \mathrm{~b}^{\wedge}$ & $0.41 \pm 0.08 b^{\wedge}$ & $23.35 \pm 0.26 b^{\wedge}$ \\
\hline & IX & $\mathrm{R}$ & $4.1 \pm 0.01 b^{*}$ & $64.7 \pm 0.10 b^{*}$ & $30.69 \pm 0.09 c^{*}$ & $1.10 \pm 0.00 \mathrm{~b}^{*}$ & $27.99 \pm 0.03 \mathrm{c}^{*}$ \\
\hline & & NR & $5.3 \pm 0.01 b^{\wedge}$ & $14.3 \pm 0.10 b^{\wedge}$ & $5.64 \pm 0.68 \mathrm{~b}^{\wedge}$ & $0.24 \pm 0.03 b^{\wedge}$ & $23.20 \pm 0.12 \mathrm{a}^{\wedge}$ \\
\hline \multirow[t]{4}{*}{ K } & $\mathrm{V}$ & $\mathrm{R}$ & $4.0 \pm 0.01 \mathrm{c}^{*}$ & $38.9 \pm 0.10 b^{*}$ & $21.62 \pm 1.23 b^{*}$ & $0.92 \pm 0.05 b^{*}$ & $23.52 \pm 0.06 b^{*}$ \\
\hline & & NR & $4.2 \pm 0.02 \mathrm{c}^{\wedge}$ & $18.1 \pm 0.50 b^{\wedge}$ & $9.85 \pm 1.68 b^{\wedge}$ & $0.47 \pm 0.06 b^{\wedge}$ & $21.16 \pm 0.83 \mathrm{a}^{\wedge}$ \\
\hline & IX & $\mathrm{R}$ & $3.9 \pm 0.01 \mathrm{c}^{*}$ & $47.6 \pm 0.40 \mathrm{c}^{*}$ & $19.43 \pm 1.19 b *$ & $0.85 \pm 0.04 c^{*}$ & $22.99 \pm 0.21 b^{*}$ \\
\hline & & NR & $3.8 \pm 0.01 \mathrm{c}^{\wedge}$ & $17 \pm 0.00 \mathrm{c}^{\wedge}$ & $8.19 \pm 0.30 \mathrm{c}^{\wedge}$ & $0.34 \pm 0.01 b^{\wedge}$ & $23.97 \pm 0.04 \mathrm{a}^{\wedge}$ \\
\hline \multirow[t]{4}{*}{$\mathrm{KO}$} & V & $\mathrm{R}$ & $3.5 \pm 0.03 \mathrm{~d}^{*}$ & $47.1 \pm 1.90 \mathrm{c}^{*}$ & $24.77 \pm 1.06 \mathrm{c}^{*}$ & $0.85 \pm 0.06 b^{*}$ & $29.24 \pm 0.62 c^{*}$ \\
\hline & & NR & $3.6 \pm 0.03 \mathrm{~d}^{\wedge}$ & $26.9 \pm 3.50 \mathrm{c}^{\wedge}$ & $30.75 \pm 0.06 c^{\wedge}$ & $1.17 \pm 0.00 \mathrm{c}^{\wedge}$ & $26.21 \pm 0.09 \mathrm{c}^{\wedge}$ \\
\hline & IX & $\mathrm{R}$ & $3.6 \pm 0.02 \mathrm{~d}^{*}$ & $68.6 \pm 0.40 \mathrm{~d}^{*}$ & $19.97 \pm 1.86 b^{*}$ & $0.69 \pm 0.05 \mathrm{~d}^{*}$ & $28.83 \pm 0.52 \mathrm{c}^{*}$ \\
\hline & & NR & $3.7 \pm 0.01 \mathrm{~d}^{\wedge}$ & $8.8 \pm 0.40 \mathrm{~d}^{\wedge}$ & $3.13 \pm 0.01 \mathrm{a}^{\wedge}$ & $0.10 \pm 0.00 \mathrm{a}^{\wedge}$ & $30.25 \pm 1.03 b^{\wedge}$ \\
\hline
\end{tabular}

The different letters denote significant differences between the particular soil physiochemical properties in the rhizosphere or non-rhizosphere soils in the same month and different marks denote significant differences between the rhizosphere and non-rhizosphere soils in the same month and in this same sapling sites $(p<$ $0.05)$

$M$ Miasteczko Śląskie, $B$ Bukowno, $K$ Katowice-Kostuchna, $K O$ Kokotek, $V$ May, $I X$ September, $R$ rhizosphere soil, $N R$ non-rhizosphere soil, $O M$ organic matter properties and soil enzyme activity in the studied areas. PCA analysis was performed without data rotation.

\section{Results}

\section{Soil properties, macronutrient concentrations, heavy metal content and bioavailability in the soil samples}

All of the investigated soils were acidic. The lowest soil $\mathrm{pH}$ value was observed at site $\mathrm{KO}$ while the highest was observed at site $\mathrm{M}$. There was a no difference in $\mathrm{pH}$ between the rhizosphere and non-rhizosphere soils (Table 3). Statistically significant differences between the rhizosphere and non-rhizosphere soils were found in the amount of organic matter $(\mathrm{OM})$, carbon and nitrogen content with higher contents recorded in the rhizosphere soil samples. The amount of organic matter ranged from $6.6 \%$ at site $\mathrm{M}$ (non-rhizosphere soil) to $68.6 \%$ at site $\mathrm{KO}$ (rhizosphere soil) (Table 3). The total concentrations of $C$ and $N$ and the $C / N$ ratio differed slightly between the sampling sites (Table 3).

No significant differences were found in the $\mathrm{K}, \mathrm{Mg}, \mathrm{Na}$, $\mathrm{Ca}, \mathrm{P}$ and $\mathrm{S}$ levels between sampling sites. We observed statistically significant higher macronutrient concentrations $(p<0.05)$ in the rhizosphere soil than in the nonrhizosphere soil at all of the sampling sites (Table 4).
There were statistically significant differences in the content of the studied metals $\left(\mathrm{HNO}_{3}\right.$ extracted and $\mathrm{CaCl}_{2}$ extracted) between the polluted and control sites. Additionally, there was a clear difference in the concentrations of metals between the rhizosphere and non-rhizosphere soil samples (Tables 5 and 6).

A particularly high PLI index was found at site $\mathrm{M}$ where the levels of heavy metals $\left(\mathrm{HNO}_{3}\right.$ extracted and $\mathrm{CaCl}_{2}$ extracted) were statistically significantly higher in the rhizosphere than in the non-rhizosphere soil samples $(p<$ 0.05). Generally, the highest levels of $\mathrm{Cd}, \mathrm{Mn}, \mathrm{Zn}$ and $\mathrm{Pb}$ $\left(\mathrm{HNO}_{3}\right.$ extracted) were observed at site $\mathrm{M}$ in the rhizosphere soil samples. The highest levels $\left(\mathrm{CaCl}_{2}\right.$ extracted) of $\mathrm{Cd}$ and $\mathrm{Zn}$ were also observed at site $\mathrm{M}$ in the rhizosphere soil samples and for $\mathrm{Pb}$ in the non-rhizosphere soils samples (Tables 5 and 6).

The following descending order of the potential bioavailability (determined as the percentages of $\mathrm{CaCl}_{2}$ extracted metals in relation to the $\mathrm{HNO}_{3}$ extracted metals) (Aydinalp and Katkat 2004; Orroño and Alavado 2009) was found among the heavy metals: $\mathrm{Cd}>\mathrm{Zn}>\mathrm{Mn}>\mathrm{Pb}>\mathrm{Fe}$ in both the rhizosphere and non-rhizosphere soils samples. At site $\mathrm{M}$, despite having the highest heavy metal concentrations in the rhizosphere soil samples, their potential bioavailability was significantly lower than in the nonrhizosphere soil samples. At the other sampling sites, in most cases, the heavy metal potential bioavailability was 
Table 4 The concentrations of macronutrients $\left(\mathrm{mg} \mathrm{kg}^{-1}\right)$ at soil samples (mean values $\pm \mathrm{SD}, n=3$ )

\begin{tabular}{|c|c|c|c|c|c|c|c|c|}
\hline & & & $\mathrm{K}$ & $\mathrm{Mg}$ & $\mathrm{Na}$ & $\mathrm{Ca}$ & $\mathrm{P}$ & $S$ \\
\hline \multirow[t]{4}{*}{ M } & $\mathrm{V}$ & $\mathrm{R}$ & $171.17 \pm 23.19 \mathrm{a}^{*}$ & $285.70 \pm 42.95 \mathrm{c}^{*}$ & $1.23 \pm 0.18 b^{*}$ & $690.75 \pm 92.84 \mathrm{ab}^{*}$ & $818.22 \pm 110.78 \mathrm{a}^{*}$ & $2028.68 \pm 301.85 \mathrm{a}^{*}$ \\
\hline & & NR & $111.87 \pm 4.67 \mathrm{a}^{\wedge}$ & $126.72 \pm 11.15 \mathrm{a}^{\wedge}$ & $0.82 \pm 0.03 \mathrm{a}^{\wedge}$ & $368.68 \pm 27.48 \mathrm{a}^{\wedge}$ & $379.08 \pm 25.59 \mathrm{a}^{\wedge}$ & $938.72 \pm 74.41 \mathrm{a}^{\wedge}$ \\
\hline & IX & $\mathrm{R}$ & $175.75 \pm 4.94 \mathrm{a}^{*}$ & $218.50 \pm 7.72 b^{*}$ & $1.07 \pm 0.03 \mathrm{ab}^{*}$ & $536.60 \pm 23.99 a^{*}$ & $653.15 \pm 10.80 a^{*}$ & $1695.25 \pm 56.23 \mathrm{a}^{*}$ \\
\hline & & NR & $113.65 \pm 12.76 \mathrm{a}^{\wedge}$ & $96.70 \pm 15.05 \mathrm{a}^{\wedge}$ & $0.70 \pm 0.05 \mathrm{a}^{\wedge}$ & $107.92 \pm 27.93 \mathrm{a}^{\wedge}$ & $308.80 \pm 40.76 \mathrm{a}^{\wedge}$ & $746.73 \pm 88.78 b^{\wedge}$ \\
\hline \multirow[t]{4}{*}{ B } & V & $\mathrm{R}$ & $198.73 \pm 26.26 \mathrm{a}^{*}$ & $210.38 \pm 26.83 b^{*} *$ & $1.10 \pm 0.13 \mathrm{a}^{*}$ & $1415.88 \pm 224.07 \mathrm{c}^{*}$ & $653.83 \pm 70.72 \mathrm{a}^{*}$ & $1810.32 \pm 234.59 \mathrm{a} *$ \\
\hline & & NR & $186.10 \pm 17.91 b^{*}$ & $229.28 \pm 27.73 c^{*}$ & $1.60 \pm 0.13 \mathrm{c}^{\wedge}$ & $1085.57 \pm 150.56 c^{\wedge}$ & $501.57 \pm 66.73 b^{*}$ & $1402.90 \pm 171.19 b^{*}$ \\
\hline & IX & $\mathrm{R}$ & $207.55 \pm 37.46 a^{*}$ & $213.65 \pm 39.19 b^{*}$ & $1.12 \pm 0.19 b^{*}$ & $1522.97 \pm 324.91 \mathrm{c}^{*}$ & $698.55 \pm 120.91 \mathrm{a}^{*}$ & $1959.63 \pm 368.36 \mathrm{a}^{*}$ \\
\hline & & NR & $161.15 \pm 3.12 \mathrm{c}^{*}$ & $202.02 \pm 5.23 \mathrm{c}^{*}$ & $1.45 \pm 0.05 \mathrm{c}^{\wedge}$ & $892.07 \pm 49.08 \mathrm{c}^{\wedge}$ & $354.60 \pm 12.83 \mathrm{ab}^{\wedge}$ & $1002.15 \pm 42.85 \mathrm{c}^{\wedge}$ \\
\hline \multirow[t]{4}{*}{ K } & $\mathrm{V}$ & $\mathrm{R}$ & $184.23 \pm 37.22 \mathrm{a}^{*}$ & $147.03 \pm 41.18 a b^{*}$ & $0.98 \pm 0.19 a^{*}$ & $795.73 \pm 157.47 b^{*}$ & $705.27 \pm 158.08 \mathrm{a}^{*}$ & $1599.17 \pm 352.92 \mathrm{a}^{*}$ \\
\hline & & NR & $175.65 \pm 5.32 b^{*}$ & $184.38 \pm 5.13 b^{*}$ & $1.15 \pm 0.05 b^{*}$ & $481.30 \pm 32.04 \mathrm{a}^{\wedge}$ & $593.90 \pm 34.00 \mathrm{~b}^{*}$ & $1272.33 \pm 60.33 b^{*}$ \\
\hline & IX & $\mathrm{R}$ & $163.45 \pm 6.49 \mathrm{a}^{*}$ & $143.22 \pm 10.19 \mathrm{a}^{*}$ & $0.82 \pm 0.03 \mathrm{a}^{*}$ & $738.97 \pm 27.42 \mathrm{a}^{*}$ & $681.50 \pm 28.98 \mathrm{a}^{*}$ & $1644.00 \pm 63.68 \mathrm{a}^{*}$ \\
\hline & & NR & $137.00 \pm 5.30 \mathrm{~b}^{\wedge}$ & $113.40 \pm 8.25 \mathrm{~b}^{\wedge}$ & $0.83 \pm 0.03 b^{*}$ & $249.58 \pm 28.94 b^{\wedge}$ & $425.42 \pm 28.11 \mathrm{~b}^{\wedge}$ & $968.27 \pm 80.36 b^{\wedge}$ \\
\hline \multirow[t]{4}{*}{$\mathrm{KO}$} & V & $\mathrm{R}$ & $137.73 \pm 23.00 a^{*}$ & $69.60 \pm 19.72 \mathrm{a}^{*}$ & $0.73 \pm 0.10 a^{*}$ & $369.22 \pm 76.62 a^{*}$ & $680.98 \pm 138.99 \mathrm{a}^{*}$ & $1452.90 \pm 302.80 a^{*}$ \\
\hline & & NR & $134.50 \pm 2.98 \mathrm{a}^{*}$ & $89.75 \pm 1.88 \mathrm{a}^{*}$ & $0.78 \pm 0.03 a^{*}$ & $279.00 \pm 9.97 \mathrm{a}^{*}$ & $515.50 \pm 16.46 b^{*}$ & $1228.33 \pm 18.13 b^{*}$ \\
\hline & IX & $\mathrm{R}$ & $182.10 \pm 4.50 \mathrm{a}^{*}$ & $98.10 \pm 9.09 \mathrm{a}^{*}$ & $1.02 \pm 0.03 \mathrm{ab}^{*}$ & $816.37 \pm 6.55 \mathrm{a}^{*}$ & $890.97 \pm 12.76 b^{*}$ & $1772.65 \pm 16.45 \mathrm{a}^{*}$ \\
\hline & & NR & $99.73 \pm 8.40 \mathrm{a}^{\wedge}$ & $52.25 \pm 10.71 \mathrm{a}$ & $0.65 \pm 0.05 \mathrm{a}^{\wedge}$ & $71.55 \pm 43.43 \mathrm{a}^{\wedge}$ & $350.42 \pm 60.29 \mathrm{ab}^{\wedge}$ & $451.65 \pm 113.58 \mathrm{a}^{\wedge}$ \\
\hline
\end{tabular}

The different letters denote significant differences between the particular macronutrient concentrations in the rhizosphere or non-rhizosphere soils in the same month and different marks denote significant differences between the rhizosphere and non-rhizosphere soils in the same month and in this same sapling sites $(p<0.05)$

$M$ Miasteczko Śląskie, $B$ Bukowno, $K$ Katowice-Kostuchna, $K O$ Kokotek, $V$ May, $I X$ September, $R$ rhizosphere soil, $N R$ non-rhizosphere soil

higher in the rhizosphere soil samples than in the nonrhizosphere soil (Table 6).

\section{Enzyme activity}

It is clear that the enzyme activity in the V. myrtillus rhizosphere soil samples was higher than it was in the nonrhizosphere samples. There was a significant difference ( $p$ $<0.05)$ between the enzyme activity in the rhizosphere and non-rhizosphere soils at the same sampling site in the same month. The highest arylsulphatase activity (Fig. 2a) was found in the rhizosphere soil at site B in May and the lowest also in the rhizosphere soil in May at site KO. The $\beta$-glucosidase activity (Fig. 2b) was higher at the other sites than at site $\mathrm{M}$ in both the rhizosphere and non-rhizosphere soils. The highest activity of this enzyme was observed in May in the rhizosphere soil at site K.

The dehydrogenase (Fig. 2c) levels ranged from 0.15 ( $\mu \mathrm{g}$

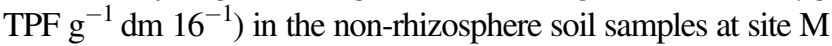
in September to $3.89\left(\mu \mathrm{g} \mathrm{TPF} \mathrm{g}{ }^{-1} \mathrm{dm} 16^{-1}\right.$ ) in the rhizosphere soil of $V$. myrtillus at site B in May. We recorded no alkaline phosphatase (Fig. 2d) activity in May in the rhizosphere and non-rhizosphere soil samples at site $\mathrm{M}$ and site $\mathrm{KO}$ (only in the non-rhizosphere soil samples). Moreover, the lowest alkaline phosphatase activity was observed in non-rhizosphere soil at $\mathrm{M}$ site in September. The highest alkaline phosphatase activity was found in the non-rhizosphere soil at site B.
The highest acid phosphatase activity (Fig. 2e) was recorded in both rhizosphere and non-rhizosphere soil samples at site B in May. At the same time, we observed the lowest activity at the sampling site B in September.

The urease activity (Fig. 2f) was higher in the rhizosphere soil samples collected in September and tended to be highest at sites $\mathrm{B}$ and $\mathrm{KO}$ while the lowest activity was observed in the non-rhizosphere soil at site $\mathrm{M}$. We found that the enzyme activity did not show any clear seasonal patterns.

Based on the soil enzyme activity, the highest values of the indexes TEI and $M_{w}$ (Table 7) were found in the $V$. myrtillus rhizosphere soil samples. The highest value of TEI was found at site B in rhizosphere soil in May and the lowest in the non-rhizosphere soil from site $\mathrm{M}$ in September. In the case of the $M_{w}$ index, the highest value was observed in the rhizosphere soil at site $\mathrm{KO}$, while the lowest was in the non-rhizosphere soil at site M.

\section{The effect of heavy metal pollution and other soil properties on the soil enzyme activity}

A more severe impact of heavy metals and soil properties on soil enzyme activity was observed in the $V$. myrtillus rhizosphere soil samples than in the non-rhizosphere soil samples at the same site (Fig. 3a, b). Generally, the activity of the soil enzymes, especially $\beta$-glucosidase and urease, decreased with increasing heavy metal concentrations for both the $\mathrm{CaCl}_{2}$ and 
Table 5 The concentration of selected metals $\left(\mathrm{mg} \mathrm{kg}^{-1}\right)$ in fractions of the soils extracted with $\mathrm{HNO}_{3}($ mean values $\pm \mathrm{SD}, n=3)$ and classification of soil samples

\begin{tabular}{|c|c|c|c|c|c|c|c|c|c|}
\hline & & & $\mathrm{Cd}$ & $\mathrm{Mn}$ & $\mathrm{Zn}$ & $\mathrm{Fe}$ & $\mathrm{Pb}$ & PLI & GRADE \\
\hline \multirow[t]{4}{*}{ M } & $\mathrm{V}$ & $\mathrm{R}$ & $33.53 \pm 3.97 b^{*}$ & $124.82 \pm 16.46 \mathrm{c} *$ & $1697.50 \pm 221.96 \mathrm{c} *$ & $4164.17 \pm 582.73 c^{*}$ & $1568.75 \pm 343.65 b^{*}$ & 22 & $\mathrm{EH}$ \\
\hline & & NR & $10.63 \pm 0.76 c^{\wedge}$ & $52.02 \pm 4.86 \mathrm{bc}^{\wedge}$ & $640.70 \pm 50.27 \mathrm{~b}^{\wedge}$ & $2451.48 \pm 208.85 \mathrm{a}^{\wedge}$ & $580.83 \pm 15.73 \mathrm{c}^{\wedge}$ & 9 & $\mathrm{EH}$ \\
\hline & IX & $\mathrm{R}$ & $28.53 \pm 0.76 c^{*}$ & $79.43 \pm 2.27 c^{*}$ & $1407.08 \pm 330.96 b *$ & $3965.83 \pm 571.08 \mathrm{c}^{*}$ & $1584.58 \pm 275.97 b^{*}$ & 16 & $\mathrm{EH}$ \\
\hline & & NR & $6.00 \pm 0.87 \mathrm{~b}^{\wedge}$ & $26.92 \pm 3.04 b^{\wedge}$ & $319.83 \pm 38.59 b^{\wedge}$ & $50411.25 \pm 6541.68 \mathrm{~b}^{\wedge}$ & $657.92 \pm 70.65 c^{\wedge}$ & 14 & $\mathrm{EH}$ \\
\hline \multirow[t]{4}{*}{ B } & $\mathrm{V}$ & $\mathrm{R}$ & $3.07 \pm 0.45 \mathrm{a}^{*}$ & $35.00 \pm 2.36 \mathrm{a}^{*}$ & $456.95 \pm 60.08 b^{*}$ & $3813.33 \pm 507.48 b^{*}$ & $206.25 \pm 24.33 \mathrm{a}^{*}$ & 5 & $\mathrm{EH}$ \\
\hline & & NR & $7.60 \pm 1.00 \mathrm{~b}^{\wedge}$ & $64.78 \pm 8.43 \mathrm{c}^{\wedge}$ & $710.80 \pm 104.83 b^{\wedge}$ & $4476.67 \pm 585.65 \mathrm{c}^{*}$ & $379.58 \pm 54.98 b^{\wedge}$ & 9 & $\mathrm{EH}$ \\
\hline & IX & $\mathrm{R}$ & $2.95 \pm 0.56 b^{*}$ & $26.75 \pm 4.54 \mathrm{a}^{*}$ & $461.27 \pm 81.61 \mathrm{a}^{*}$ & $3272.08 \pm 434.66 \mathrm{bc}^{*}$ & $203.33 \pm 39.69 a^{*}$ & 4 & $\mathrm{EH}$ \\
\hline & & NR & $5.50 \pm 0.35 \mathrm{ba}^{\wedge}$ & $45.32 \pm 1.21 \mathrm{c}^{\wedge}$ & $532.40 \pm 23.48 \mathrm{c} *$ & $3382.92 \pm 180.11 \mathrm{a} *$ & $287.50 \pm 11.25 b^{\wedge}$ & 14 & $\mathrm{EH}$ \\
\hline \multirow[t]{4}{*}{ K } & $\mathrm{V}$ & $\mathrm{R}$ & $0.40 \pm 0.13 a^{*}$ & $79.62 \pm 4.65 \mathrm{c}^{*}$ & $40.42 \pm 11.11 \mathrm{a}^{*}$ & $2196.47 \pm 596.86 \mathrm{a}^{*}$ & $61.55 \pm 17.02 \mathrm{a}^{*}$ & 2 & M \\
\hline & & NR & $0.30 \pm 0.05 \mathrm{a}^{*}$ & $44.40 \pm 2.62 b^{*}$ & $47.60 \pm 2.01 \mathrm{a}^{*}$ & $3514.05 \pm 42.39 \mathrm{~b}^{\wedge}$ & $105.88 \pm 6.98 \mathrm{a}^{\wedge}$ & 2 & M \\
\hline & IX & $\mathrm{R}$ & $0.40 \pm 0.06 \mathrm{a}^{*}$ & $77.51 \pm 6.11 \mathrm{c}^{*}$ & $41.28 \pm 3.10 \mathrm{a}^{*}$ & $2369.70 \pm 189.81 b^{*}$ & $64.43 \pm 3.85 \mathrm{a}^{*}$ & 2 & M \\
\hline & & NR & $0.12 \pm 0.03 \mathrm{a}^{\wedge}$ & $25.35 \pm 1.20 \mathrm{~b}^{\wedge}$ & $23.10 \pm 1.90 \mathrm{a}^{\wedge}$ & $2578.18 \pm 126.80 \mathrm{a}^{*}$ & $62.57 \pm 6.38 \mathrm{a}^{*}$ & 2 & M \\
\hline \multirow[t]{4}{*}{$\mathrm{KO}$} & $\mathrm{V}$ & $\mathrm{R}$ & $0.51 \pm 0.08 \mathrm{a}^{*}$ & $12.75 \pm 2.66 \mathrm{a}^{*}$ & $35.47 \pm 8.80 \mathrm{a}^{*}$ & $1217.40 \pm 269.41 \mathrm{a}^{*}$ & $44.62 \pm 9.38 \mathrm{a}^{*}$ & 0.1 & $\mathrm{~N}$ \\
\hline & & NR & $1.14 \pm 0.42 b^{*}$ & $19.62 \pm 7.68 \mathrm{a}^{*}$ & $38.56 \pm 13.65 \mathrm{a}^{*}$ & $1935.27 \pm 50.44 \mathrm{a}^{\wedge}$ & $76.17 \pm 2.87 \mathrm{a}^{\wedge}$ & 0.1 & $\mathrm{~N}$ \\
\hline & IX & $\mathrm{R}$ & $0.50 \pm 0.05 \mathrm{a}^{*}$ & $33.00 \pm 11.17 \mathrm{a}^{*}$ & $36.98 \pm 0.40 \mathrm{a}^{*}$ & $1083.03 \pm 275.37 \mathrm{a}^{*}$ & $28.88 \pm 0.14 \mathrm{a}^{*}$ & 0.1 & $\mathrm{~N}$ \\
\hline & & NR & $0.14 \pm 0.02 \mathrm{a}^{\wedge}$ & $5.83 \pm 1.37 \mathrm{a}^{\wedge}$ & $11.82 \pm 5.52 \mathrm{a}^{\wedge}$ & $1260.95 \pm 190.44 \mathrm{a}^{*}$ & $26.73 \pm 6.41 \mathrm{a}^{\wedge}$ & 0.1 & $\mathrm{~N}$ \\
\hline
\end{tabular}

The different letters denote significant differences between the particular $\mathrm{HNO}_{3}$ extracted metal concentrations in the rhizosphere or nonrhizosphere soils in the same month and different marks denote significant differences between the rhizosphere and non-rhizosphere soils in the same month and in this same sapling sites $(p<0.05)$

$M$ Miasteczko Śląskie, $B$ Bukowno, $K$ Katowice-Kostuchna, $K O$ Kokotek, $V$ May, $I X$ September, R rhizosphere soil, $N R$ non-rhizosphere soil, $P L I$ pollution load index, $N$ no pollution $(\mathrm{PLI}<1)$, M moderate pollution $(1<\mathrm{PLI}<2), E H$ extremely heavy pollution $(3<\mathrm{PLI})$

Table 6 The concentration of selected metals $\left(\mathrm{mg} \mathrm{kg}^{-1}\right)$ in fractions of the soils extracted with $\mathrm{CaCl}_{2}$ (mean values $\pm \mathrm{SD}, n=3$ ) and their potential bioavailability $(\%)$

\begin{tabular}{|c|c|c|c|c|c|c|c|c|c|c|c|}
\hline & & & $\mathrm{Cd}$ & & $\mathrm{Mn}$ & & $\mathrm{Zn}$ & $\mathrm{Fe}$ & & $\mathrm{Pb}$ & \\
\hline \multirow[t]{4}{*}{ M } & $\mathrm{V}$ & $\mathrm{R}$ & $16.15 \pm 2.75 b^{*}$ & 48.00 & $14.81 \pm 2.18 \mathrm{a}^{*}$ & 12.17 & $648.60 \pm 110.70 \mathrm{c} 38.14$ & $0.10 \pm 0.03 a^{*}$ & 0.00 & $23.35 \pm 2.45 b^{*}$ & 1.52 \\
\hline & & NR & $7.80 \pm 0.38 \mathrm{~d}^{\wedge}$ & 73.67 & $7.71 \pm 0.53 \mathrm{a}^{\wedge}$ & 14.90 & $389.80 \pm 9.30 c^{\wedge} 61.06$ & $0.28 \pm 0.03 \mathrm{a}^{\wedge}$ & 0.01 & $10.75 \pm 0.75 b^{\wedge}$ & 1.85 \\
\hline & IX & $\mathrm{R}$ & $15.60 \pm 0.50 \mathrm{~b} *$ & 54.73 & $15.23 \pm 0.23 \mathrm{a}^{*}$ & 19.18 & $564.25 \pm 12.95 \mathrm{c} * 41.35$ & $0.48 \pm 0.02 \mathrm{a}^{*}$ & 0.01 & $23.90 \pm 1.20 \mathrm{~b}^{*}$ & 1.55 \\
\hline & & NR & $5.68 \pm 0.15 c^{\wedge}$ & 92.17 & $5.28 \pm 0.07 \mathrm{a}^{\wedge}$ & 19.77 & $183.90 \pm 3.14 c^{\wedge} 58.00$ & $1.33 \pm 0.12 \mathrm{a}^{\wedge}$ & 0.00 & $47.89 \pm 1.77 \mathrm{~b}^{\wedge}$ & 7.32 \\
\hline \multirow[t]{4}{*}{ B } & V & $\mathrm{R}$ & $1.61 \pm 0.03 \mathrm{a}^{*}$ & 53.42 & $20.46 \pm 0.18 b^{*}$ & 58.65 & $201.11 \pm 2.57 \mathrm{~b} * 44.61$ & $29.43 \pm 0.49 \mathrm{c}^{*}$ & 0.78 & $3.69 \pm 0.35 \mathrm{a}^{*}$ & 1.82 \\
\hline & & NR & $3.26 \pm 0.19 \mathrm{c}^{\wedge}$ & 43.30 & $16.03 \pm 0.84 \mathrm{a}^{\wedge}$ & 25.05 & $237.12 \pm 13.72 b^{\wedge} 33.83$ & $1.65 \pm 0.18 \mathrm{ab}^{\wedge}$ & 0.04 & $3.76 \pm 1.43 \mathrm{a}^{*}$ & 1.00 \\
\hline & IX & $\mathrm{R}$ & $1.01 \pm 0.42 \mathrm{a}^{*}$ & 33.01 & $8.12 \pm 4.04 \mathrm{a}^{*}$ & 29.10 & $137.06 \pm 54.47 \mathrm{~b} * 28.86$ & $20.35 \pm 6.50 b^{*}$ & 0.61 & $3.44 \pm 1.25 \mathrm{a}^{*}$ & 1.67 \\
\hline & & NR & $2.73 \pm 0.09 b^{\wedge}$ & 49.82 & $5.44 \pm 0.16 \mathrm{a}^{*}$ & 12.00 & $221.80 \pm 6.67 \mathrm{~b} * 41.74$ & $0.97 \pm 0.07 \mathrm{a}^{\wedge}$ & 0.03 & $2.37 \pm 0.08 \mathrm{a}^{*}$ & 0.82 \\
\hline \multirow[t]{4}{*}{ K } & V & $\mathrm{R}$ & $0.40 \pm 0.03 \mathrm{a}^{*}$ & 99.97 & $65.27 \pm 14.28 b^{*}$ & 80.28 & $20.46 \pm 0.89 a * 53.36$ & $22.43 \pm 1.82 b^{*}$ & 1.05 & $2.90 \pm 1.86 \mathrm{a}^{*}$ & 4.42 \\
\hline & & NR & $0.16 \pm 0.07 \mathrm{a}^{\wedge}$ & 56.51 & $24.24 \pm 8.86 \mathrm{~b}^{\wedge}$ & 55.37 & $10.11 \pm 3.86 a^{\wedge} 21.47$ & $3.98 \pm 1.41 b c^{\wedge}$ & 0.11 & $3.14 \pm 0.69 a^{*}$ & 2.99 \\
\hline & IX & $\mathrm{R}$ & $0.38 \pm 0.03 a^{*}$ & 85.77 & $61.03 \pm 2.03 b^{*}$ & 79.22 & $20.81 \pm 2.76 \mathrm{a} * 50.89$ & $29.62 \pm 7.74 b^{*}$ & 1.27 & $2.20 \pm 0.89 a^{*}$ & 3.47 \\
\hline & & NR & $0.11 \pm 0.05 \mathrm{a}^{\wedge}$ & 67.50 & $9.99 \pm 3.32 b^{\wedge}$ & 39.66 & $5.48 \pm 2.13 \mathrm{a}^{\wedge} 24.07$ & $6.18 \pm 2.28 \mathrm{~b}^{\wedge}$ & 0.24 & $3.71 \pm 1.09 \mathrm{a}^{*}$ & 6.08 \\
\hline \multirow[t]{4}{*}{$\mathrm{KO}$} & V & $\mathrm{R}$ & $0.37 \pm 0.12 \mathrm{a}^{*}$ & 73.76 & $10.27 \pm 1.28 \mathrm{a}^{*}$ & 83.11 & $24.78 \pm 3.55 \mathrm{a} * 72.31$ & $34.78 \pm 4.68 \mathrm{c}^{*}$ & 2.95 & $2.98 \pm 0.84 a^{*}$ & 6.92 \\
\hline & & NR & $0.13 \pm 0.03 \mathrm{a}^{\wedge}$ & 13.76 & $13.85 \pm 0.10 \mathrm{a}^{*}$ & 64.70 & $34.382 .41 \mathrm{a}^{*}$ & $6.12 \pm 2.38 \mathrm{c}^{\wedge}$ & 0.32 & $6.05 \pm 4.56 \mathrm{ab}^{\wedge}$ & 7.90 \\
\hline & IX & $\mathrm{R}$ & $0.45 \pm 0.00 \mathrm{a}^{*}$ & 89.74 & $32.03 \pm 5.95 b^{*}$ & 80.13 & $25.81 \pm 1.89 a^{*} 69.77$ & $6.71 \pm 1.53 \mathrm{a}^{*}$ & 0.66 & $1.00 \pm 0.23 \mathrm{a}^{*}$ & 3.45 \\
\hline & & NR & nd & 0.00 & $1.74 \pm 0.16 \mathrm{a}^{\wedge}$ & 31.59 & $9.23 \pm 1.11 \mathrm{a}^{\wedge} 98.57$ & $16.94 \pm 1.74 \mathrm{c}^{\wedge}$ & 1.38 & $3.00 \pm 0.48 \mathrm{a}^{\wedge}$ & 11.60 \\
\hline
\end{tabular}

The different letters denote significant differences between the particular $\mathrm{CaCl}_{2}$ extracted metal concentrations in the rhizosphere or nonrhizosphere soils in the same month and different marks denote significant differences between the rhizosphere and non-rhizosphere soils in the same month and in this same sapling sites $(p<0.05)$

$M$ Miasteczko Śląskie, $B$ Bukowno, $K$ Katowice-Kostuchna, $K O$ Kokotek, $V$ May, $I X$ September, $R$ rhizosphere soil, $N R$ non-rhizosphere soil, $n d$ not detected, potential bioavailability determined as the percentages of $\mathrm{CaCl}_{2}$ extracted metals in relation to the $\mathrm{HNO}_{3}$ extracted metals 

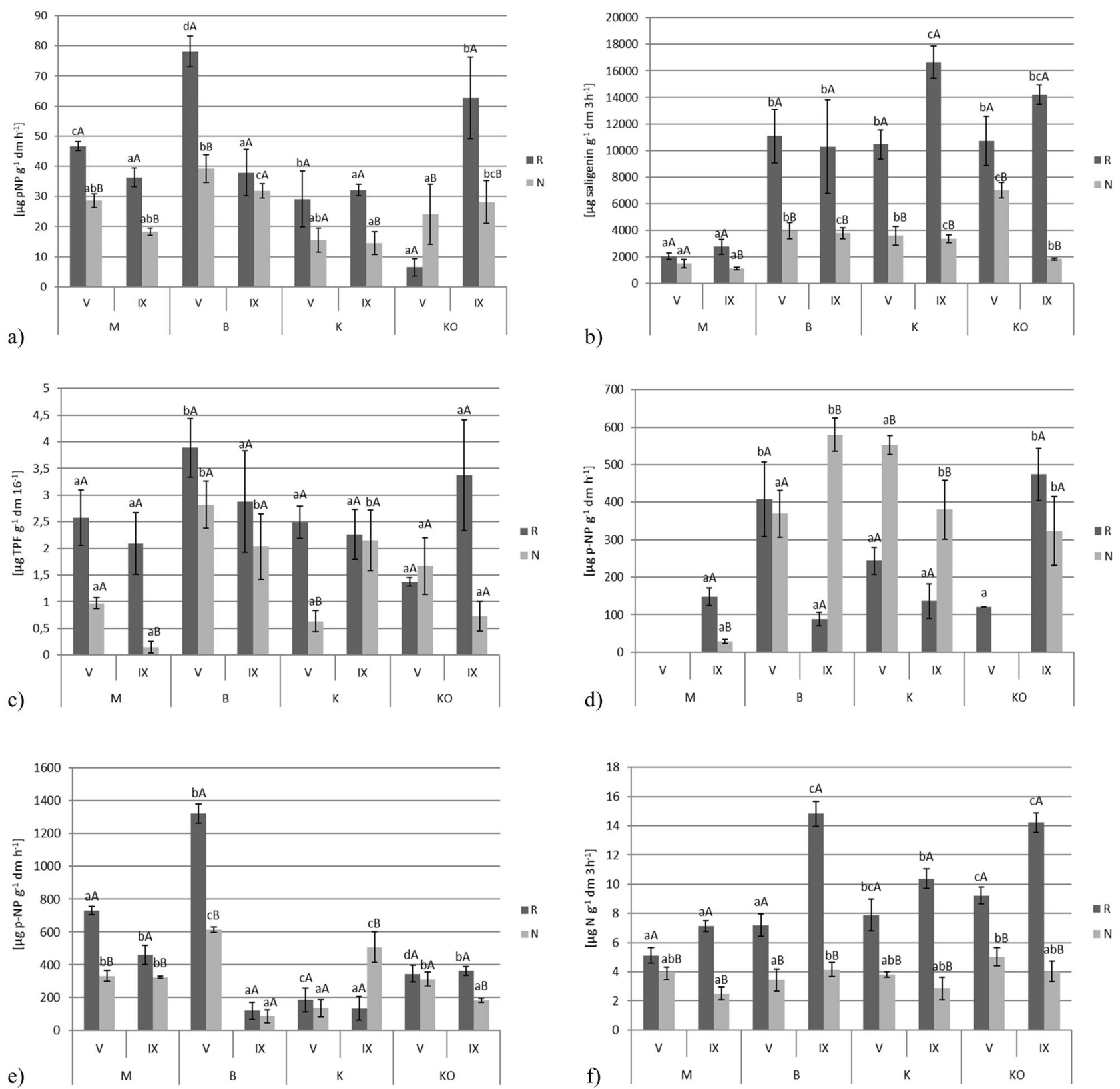

Fig. 2 Arylsulphatase (a), $\beta$-glucosidase (b), dehydrogenase (c), alkaline phosphatase (d), acid phosphatase (e), urease (f) activities in rhizosphere and non-rhizosphere soil of investigated sites (mean values $\pm \mathrm{SD}, n=3$ ). The different small letters denote significant differences between the particular metal concentrations in the rhizosphere or non-rhizosphere soils in the same month and big letters denote

significant differences between the rhizosphere and non-rhizosphere soils in the same month and in this same sampling sites $(p<0.05)$. M Miasteczko Śląskie, B Bukowno, K Katowice-Kostuchna, KO Kokotek, V May, IX September, R rhizosphere soil, NR nonrhizosphere soil

$\mathrm{HNO}_{3}$ extracted values. A positive correlation coefficient was also obtained between $\beta$-glucosidase and urease and soil properties such as the organic matter content and the $C$ and $N$ concentrations. There were highly significant correlations between the activity of all of the investigated soil enzymes and the macronutrient levels in both the rhizosphere and nonrhizosphere soils (Fig. 3a, b).

A PCA analysis of the rhizosphere soils (Fig. 4a) showed that the factors that correlated with the first axis explained $96.6 \%$ of the variability, thus indicating negative correlations between the $\beta$-glucosidase, urease and alkaline phosphatase activity and the $\mathrm{pH}$ value and the $\mathrm{Zn}, \mathrm{Pb}, \mathrm{Cd}$ content $\left(\mathrm{CaCl}_{2}\right.$ extracted $)$, but a positive correlation between these enzymes and the $C, N$, OM 
Table 7 Chosen indexes and indices of soil samples

\begin{tabular}{|c|c|c|c|c|c|c|c|c|c|c|}
\hline & & & TEI & $M_{w}$ & ACR & & & & & \\
\hline & & & & & AS & $\beta G$ & Deh & AlP & AP & Ure \\
\hline M & V & $\mathrm{R}$ & $5.68 \mathrm{a}^{*}$ & $130.99 a^{*}$ & 620.09 & -80.93 & 87.84 & 0 & 111.56 & -93.60 \\
\hline & & NR & $3.03 \mathrm{a}^{\wedge}$ & $38.04 \mathrm{a}^{\wedge}$ & 18.91 & -78.58 & -41.62 & 0 & 6.21 & -91.06 \\
\hline & IX & $\mathrm{R}$ & $5.45 \mathrm{a}^{*}$ & $106.48 \mathrm{a} *$ & -4.18 & -80.55 & -37.86 & -68.98 & 26.72 & -94.21 \\
\hline & & NR & $2.14 \mathrm{a}^{\wedge}$ & $23.38 \mathrm{a}^{\wedge}$ & -35.07 & -38.40 & -79.00 & -91.02 & 77.47 & -92.81 \\
\hline B & V & $\mathrm{R}$ & $12.23 b^{*}$ & $857.13 c^{*}$ & 1105.85 & 3.56 & 183.75 & 239.34 & 282.79 & -91.00 \\
\hline & & NR & $6.85 b^{\wedge}$ & $234.52 \mathrm{c}^{\wedge}$ & 62.98 & -43.30 & 68.80 & 0 & 96.88 & -92.12 \\
\hline & IX & $\mathrm{R}$ & $7.06 \mathrm{a}^{*}$ & $135.35 \mathrm{a}^{*}$ & -39.61 & -27.69 & -14.65 & -81.49 & -67.70 & -87.98 \\
\hline & & NR & $5.81 \mathrm{c}^{\wedge}$ & $95.29 \mathrm{bc}^{\wedge}$ & 13.25 & 106.10 & 178.29 & 79.77 & -53.97 & -88.05 \\
\hline K & V & $\mathrm{R}$ & $6.40 a^{*}$ & 167.46ab* & 349.08 & -2.44 & 81.67 & 101.80 & -46.52 & -90.14 \\
\hline & & NR & $4.56 \mathrm{a}^{\wedge}$ & $124.48 b^{*}$ & -35.14 & -48.59 & -62.04 & 0 & -56.82 & -91.25 \\
\hline & IX & $\mathrm{R}$ & 7.13a* & $129.65 \mathrm{a} *$ & -48.79 & 17.05 & -32.98 & -71.33 & -63.45 & -91.57 \\
\hline & & NR & $5.35 b^{*}$ & $151.04 \mathrm{c} *$ & -48.69 & 83.96 & 194.75 & 17.68 & 177.22 & -91.78 \\
\hline KO & V & $\mathrm{R}$ & $5.31 a^{*}$ & $219.9 b^{*}$ & 0 & 0 & 0 & 0 & 0 & 0 \\
\hline & & NR & $4.21 \mathrm{a}^{*}$ & $85.11 \mathrm{ab}^{\wedge}$ & 0 & 0 & 0 & 0 & 0 & 0 \\
\hline & IX & $\mathrm{R}$ & $10.82 b^{*}$ & $577.58 b^{*}$ & 0 & 0 & 0 & 0 & 0 & 0 \\
\hline & & NR & $3.92 \mathrm{ab}^{\wedge}$ & $44.79 \mathrm{ab}^{\wedge}$ & 0 & 0 & 0 & 0 & 0 & 0 \\
\hline
\end{tabular}

The different letters denote significant differences between particular indexes (TEI and $\mathrm{M}_{w}$ ) in the rhizosphere or non-rhizosphere soils in the same month and different marks denote significant differences between the rhizosphere and non-rhizosphere soils in the same month and in this same sapling sites $(p<$ $0.05)$

$M$ Miasteczko Śląskie, $B$ Bukowno, $K$ Katowice-Kostuchna, $K O$ Kokotek, $V$ May, $I X$ September, $R$ rhizosphere soil, $N R$ non-rhizosphere soil, TEI total enzyme activity index, $M_{w}$ potential biochemical soil fertility index, $A C R$ enzyme activity change ratio, $A S$ arylsulphatase, $\beta G \beta$-glucosidase, Deh dehydrogenase, $A l P$ alkaline phosphatase, $A P$ acid phosphatase, Ure urease content. In turn, for the non-rhizosphere soils (Fig. 4b), the first axis explained $99.7 \%$ of the variability. The factors for which there was a positive correlation were the $\beta$-glucosidase activity and $P$ content, urease activity and $C$ content and acid phosphatase and $\mathrm{pH}$ value. Negative correlations were found between the alkaline phosphatase and dehydrogenase activity and the $\mathrm{Cd}$, $\mathrm{Znb}, \mathrm{Pb}$ and $\mathrm{Cdb}$ content.

The ACR (enzyme activity change ratio) varied from -94.21 to 1105.85 for the $V$. myrtillus rhizosphere soil and from -91.78 to 194.75 for the non-rhizosphere soil (Table 7).

\section{Biological indices}

A total of 20179 microarthropods from nine different taxa were extracted from the soil samples (Table 8). Mites were by far the most abundant taxa in the samples (Table 8). The highest number of microarthropods (2486) were collected in the rhizosphere soil samples at site KO. The highest value of the QBS and FEMI indices were found in the rhizosphere soil at the control site $\mathrm{KO}$ and the lowest in the non-rhizosphere soil samples at contaminated site $\mathrm{M}$ (Table 8).

\section{Discussion}

\section{Assessment of heavy metal pollution}

Very high total concentrations of the studied heavy metals were observed in the soils from Miasteczko Śląskie (site $\mathrm{M})$. The concentrations of $\mathrm{Cd}, \mathrm{Zn}$ and $\mathrm{Pb}$ exceeded the permissible levels according to the Regulations of the Polish Minister of the Environment (2002). Under this regulation, the maximum allowable concentrations of these metals in the soil should not exceed $3 \mathrm{mg} \mathrm{kg}^{-1}, 300 \mathrm{mg} \mathrm{kg}^{-1}$ and $100 \mathrm{mg} \mathrm{kg}^{-1}$, respectively. Excessive concentrations of $\mathrm{Cd}$, $\mathrm{Zn}$ and $\mathrm{Pb}$ were also found at Bukowno (site B). These results were like our previous studies that had been carried out in the same or similar areas (e.g., Kandziora-Ciupa et al. 2017).

At Miasteczko Śląskie, the rhizosphere soils accumulated more heavy metals than the non-rhizosphere soils, while at the other sampling sites the heavy metal content was lower in the rhizosphere than in the non-rhizosphere soils in most cases.

In this study, the pollution load index was also determined, which was particularly high at site $\mathrm{M}$. We agree with Yang et al. (2016) that PLI is a simple and useful means to 


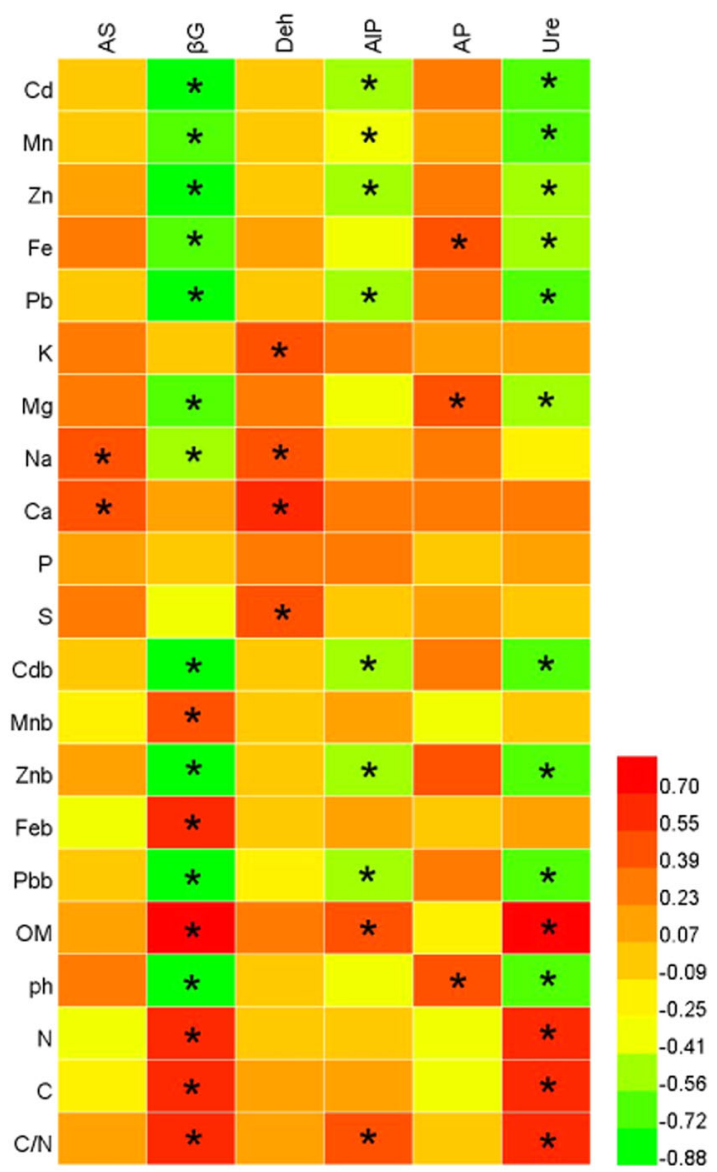

a)

Fig. 3 Heat map of the correlation between soil enzyme activities and properties in rhizosphere (a) and non-rhizosphere (b) soils. Strong positive correlation (red), weak correlation (yellow), strong negative correlation (green); *significant correlation $(p<0.05)$. AS

assess the overall level of heavy metal pollution between different sampling sites.

Many studies have emphasized that the total concentration of heavy metals in soils provides little information on their mobility, bioavailability and, hence, their potential toxicity (Feng et al. 2005; Boussen et al. 2013; Wójcik et al. 2014). It has been widely accepted that heavy metal availability has a major influence on the toxic effects in biological systems (Olaniran et al. 2013; Yang et al. 2017). For the extraction of heavy metals, a $0.01 \mathrm{M} \mathrm{CaCl}_{2}$ solution has been proposed as the most preferred extraction medium solution (Menzies et al. 2007; Boussen et al. 2013). The following descending order of bioavailability was found for the heavy metals that were analyzed: $\mathrm{Cd}>\mathrm{Zn}>\mathrm{Mn}>\mathrm{Pb}>\mathrm{Fe}$ in both the rhizosphere and non-rhizosphere soils samples. Similar results were found by Szarek-Łukaszewska and Niklińska (2002) in $\mathrm{Zn}-\mathrm{Pb}$ ore tailings or their immediate vicinity and by Wójcik et al. (2014) in $\mathrm{Zn}-\mathrm{Pb}$ waste deposits in southern Poland.

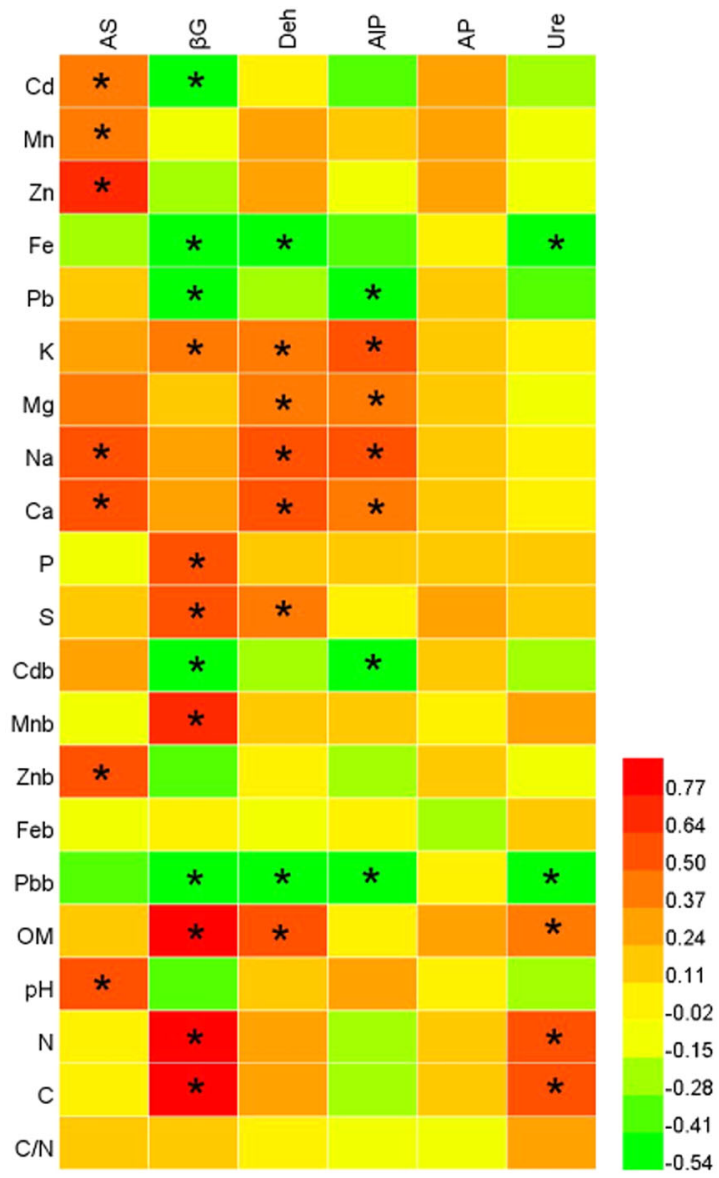

b)

arylsulphatase, $\beta \mathrm{G} \beta$-glucosidase, Deh dehydrogenase, AlP alkaline phosphatase, AP acid phosphatase, Ure urease, OM organic matter, $\mathrm{b}$ potentially bioavailable elements

At site M, the bioavailability of the heavy metals in the rhizosphere soils was significantly lower than in the nonrhizosphere soils samples, and the reason was attributed to an increase in $\mathrm{pH}$ in the rhizosphere soil (Wang et al. 2002). Among soil properties, soil $\mathrm{pH}$ had the greatest impact on the desorption and bioavailability of heavy metals, because of its strong effects on solubility and speciation of heavy metals both in the soil as a whole and particularly in the soil solution (Müehlbachová et al. 2005; Chen et al. 2013). At high $\mathrm{pH}$, metals tend to form insoluble metal mineral phosphates and carbonates, whereas at low $\mathrm{pH}$ they tend to be found as free ionic species or as soluble organometals and are more bioavailable (Olaniran et al. 2013). At the other sampling sites, in most cases, heavy metal bioavailability was higher in the rhizosphere soils samples. Yang et al. (2017) detected that the availability of $\mathrm{Pb}$ was significantly higher in bulk soil than that in rhizosphere soil at medium and high pollution levels. Low molecular weight organic acids (e.g., oxalate), which are released by plant roots can form complexes with heavy metals, which can 


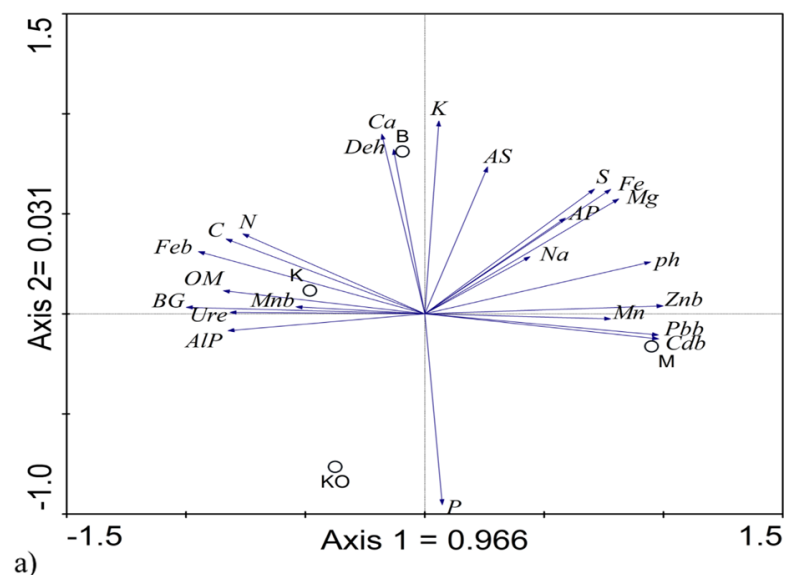

a)

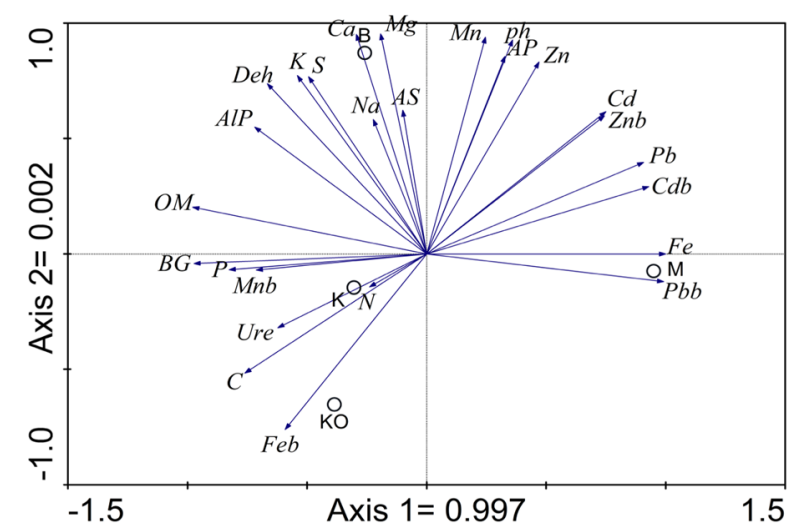

b)

Fig. 4 Principal Component Analysis (PCA) biplot of sampling sites and heavy metal concentrations and enzyme activities and biochemical parameters in the rhizosphere (a) and non-rhizosphere (b) soil samples. M Miasteczko Śląskie, B Bukowno, K Katowice-Kostuchna, KO Kokotek, AS arylsulphatase, BG $\beta$-glucosidase, Deh dehydrogenase, AlP alkaline phosphatase, AP acid phosphatase, Ure urease, OM organic matter, $\mathrm{Xb}$ potentially bioavailable elements

immobilize and reduce their availability in rhizosphere soil (Wang et al. 2002; Luo et al. 2017).

\section{Soil enzyme activity}

\section{Rhizosphere effects on enzyme activity}

In general, all of the soil enzyme activity that was measured in this study exhibited higher values in the rhizosphere soils than in the non-rhizosphere soil. The higher enzyme activity of the rhizosphere may be due to the physiological activity of the roots, which produce and release large amounts of enzymes under the influence of heavy metals or via the lysis of root cells. Moreover, it may also depend on the physiological metabolic activities of the diverse microbial populations, which produce specific soil enzymes (Gianfreda 2015; Xiao et al. 2017; Yang et al. 2017).
Effects of the soil properties and macronutrient content on the enzyme activity

In this study, the physicochemical properties of the rhizosphere soils such as the levels of $\mathrm{OM}, \mathrm{C}, \mathrm{N}, \mathrm{K}, \mathrm{Mg}, \mathrm{Na}, \mathrm{Ca}$, $\mathrm{P}$ and $\mathrm{S}$ were significantly higher than those of the nonrhizosphere soils. According to Wang et al. (2009), this may be the result of the exudates and metabolites that are released by the roots and microbial metabolites in rhizosphere soil. Garcia et al. (2005) found that in all six investigated plant species, there was an increase in the organic matter content in the rhizosphere.

A factor that may largely determine soil enzyme activity is the organic matter content, which correlates with several biochemical functions of the soil enzymes (Nannipieri et al. 2002; Wahsha et al. 2017). The organic matter content provides a better soil environmental condition for stabilizing and protecting enzymes. A higher organic carbon content supports a larger microbial biomass, which leads to an increase in the enzymatic activity (Bartkowiak et al. 2017). Many authors have found positive correlations between soil enzyme activity and organic matter content (e.g., Tan et al. 2014; Gucwa-Przepióra et al. 2016). In the present study, we found a statistically significant correlation between the activity of $\beta$-glucosidase, alkaline phosphatase, and urease in the rhizosphere soils, along with the dehydrogenase and organic matter content in the nonrhizosphere soils. This supports the findings of Patel and Patra (2014), who found that the activity of acid and alkaline phosphatase and dehydrogenase in tannery sludge that was rich in heavy metals were positively correlated with organic matter.

Soil $\mathrm{pH}$ has been identified as one of the key abiotic environmental factors shape soil enzyme activity in soils (Turner 2010; Pan et al. 2018). Effron et al. (2004) reported that the enzyme activity was sensitive to $\mathrm{pH}$ changes and that different enzymes can respond differently to the same $\mathrm{pH}$. In this study, the urease and beta-glucosidase activity levels were negatively correlated with the soil $\mathrm{pH}$ values, while by contrast, the acid phosphatase and arylsulphatase levels increased with higher soil $\mathrm{pH}$ values. In rhizosphere soils, changes in soil $\mathrm{pH}$ values have a stronger influence on the enzyme activity than in non-rhizosphere soil. Previous studies have reported that urease, $\beta$-glucosidase, and acid phosphatase are significantly affected by changes in soil $\mathrm{pH}$ (Acosta-Martinez and Tabatabai 2000; Hinojosa et al. 2004).

Analysis of the data showed that there were highly significant correlations between all of soil enzyme activity and macronutrient contents in both the rhizosphere and nonrhizosphere soils that were investigated. According to Chróst (1991), microorganisms control their enzyme production in response to nutrient availability. The strong 


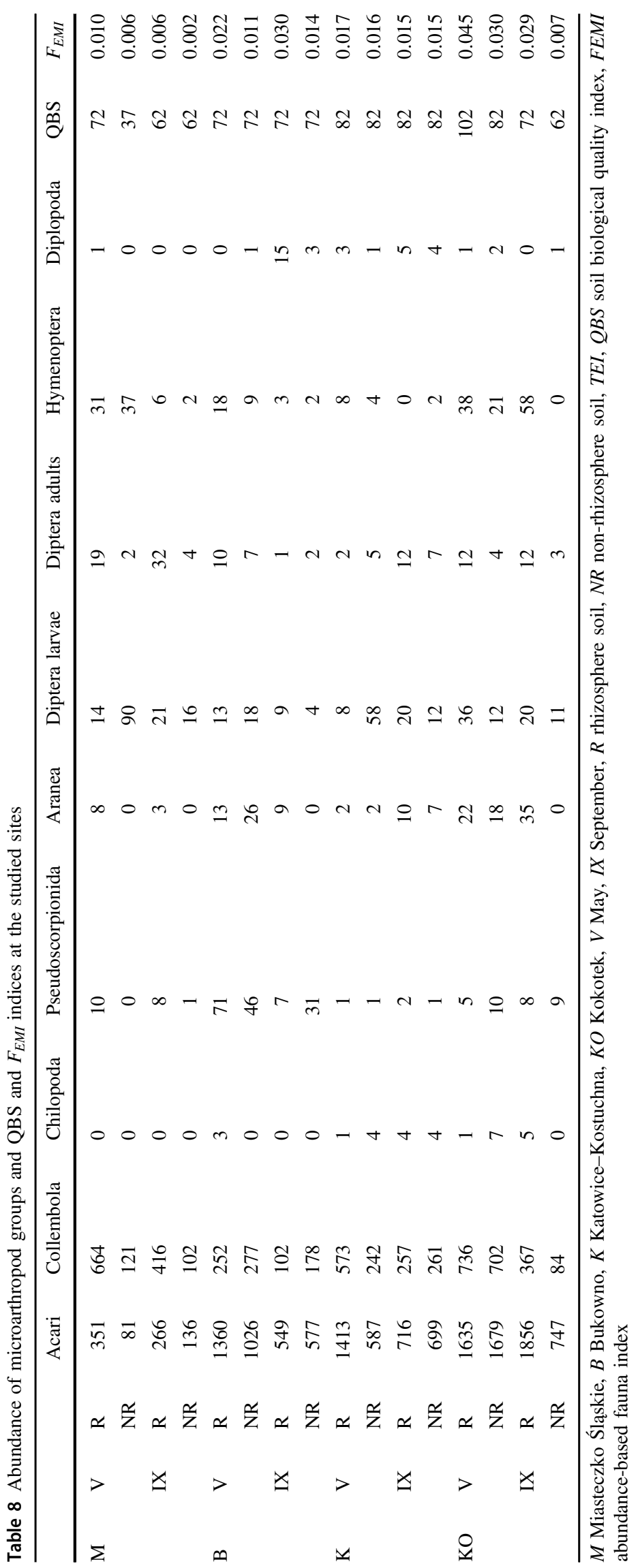


dependency between soil enzyme activity and different soil properties confirms that soil enzyme activity provides a meaningful integrative measure of the soil physicochemical properties and biological soil fertility, which, thus, may play a role in monitoring soil biological quality (Aşkın, Kizılkaya 2006; Tan et al. 2014).

In contrast, Wyszkowska and Wyszkowski (2003) proposed a potential biochemical soil fertility index $\left(M_{w}\right)$, which could be more efficient in making predictions about soil fertility than the activity of a single soil enzyme. In the present study, we found that the $M_{w}$ was higher in the rhizosphere soil; however, the $M_{w}$ index did not correlate with. the studied soil properties.

\section{Effects of heavy metals on the enzyme activity}

Analysis of many different enzyme activities can provide a better picture of the status of soil processes and functioning (Acosta-Martinez et al. 2003), therefore, in this study, we examined the activity of six soil enzymes.

The effects of heavy metals on the enzyme activity are complex. The response of different enzymes to the same metal can vary greatly and the same enzyme may respond differently to different metals (He et al. 2003; Li et al. 2009).

The effects of heavy metals on soil enzyme activity have been reported in many previous studies, but they were mostly concentrated on the impact of the total concentrations of heavy metals on these enzymes. However, as was previously mentioned, biological systems and soil quality are more dependent on the bioavailable heavy metal concentration (Hinojosa et al. 2004). Therefore, we focused on the effect of the potentially bioavailable heavy metal fraction on enzyme activity. In this study, the various soil metals showed effects on soil enzyme activity and these effects differed between the rhizosphere and nonrhizosphere soils.

$\beta$-glucosidase is a useful indicator of soil quality and its activity may indicate changes in the level of organic carbon earlier than measurements using other methods (Das and Varma 2011). This enzyme plays an important role in the degradation of the organic $\mathrm{C}$ compounds in the soil and are important energy sources for microorganism (Acosta-Martinez and Tabatabai 2000; Narendrula-Kotha and Nkongolo 2017). Turner et al. (2002) and Hinojosa et al. (2004) found that $\beta$-glucosidase is a decisive indicator of soil contamination by toxic metals. In our study, these findings were supported because we found the lowest $\beta$-glucosidase activity at the site with the highest $\mathrm{Cd}, \mathrm{Zn}$ and $\mathrm{Pb}$ concentrations. These metals strongly inhibited the $\beta$-glucosidase activity in both the rhizosphere and nonrhizosphere soils. In contrast, Narendula-Kotha and Nkongolo (2017) reported a higher $\beta$-glucosidase activity in metal-contaminated sites. Similarly, in our work, we found a positive correlation between the $\mathrm{Mn}$ and $\mathrm{Fe}$ and $\beta$-glucosidase activity.

Urease catalyzes the hydrolysis of urea in soil, which induces the formation of carbon dioxide and ammonia (Baćmaga et al. 2015). In the present study, the correlation coefficients confirmed that urease activity was negatively correlated to $\mathrm{Cd}, \mathrm{Zn}, \mathrm{Pb}$ in the rhizosphere soils and to $\mathrm{Pb}$ in the non-rhizosphere soils. Similar results were obtained by Angelovičová et al. (2014) who found that $\mathrm{Pb}$ and $\mathrm{Zn}$ decreased the urease activity levels in soils. According to Gao (2010), urease appears to be more sensitive to pollution stress than phosphatases.

Phosphatase plays an important role in transforming organic phosphorus into an inorganic form that is suitable for plant uptake (Cang et al. 2009; Angelovičová et al. 2014). We observed an inhibitory effect of $\mathrm{Cd}, \mathrm{Pb}$ and $\mathrm{Zn}$ on the alkaline phosphatase activity. Also, Pattnaik and Equeenuddin (2016) found that alkaline phosphatase was negatively correlated with the examined metals except for $\mathrm{Pb}$. Wahsha et al. (2017) reported negative correlations between $\mathrm{Fe}, \mathrm{Pb}, \mathrm{Zn}$ and $\mathrm{Cu}$ and alkaline phosphatase.

Dehydrogenase plays a significant role in soil through the biological oxidation of soil carbon and transfers the hydrogen ion from organic substrates to inorganic substances (Zhang et al. 2008). Dehydrogenase is most sensitive to heavy metal pollution (Khan et al. 2007). In the present study, we only found a negative correlation between $\mathrm{Pb}$ and dehydrogenase activity in the non-rhizosphere soils. Similar results were obtained by Pan and Yu (2011), who found that the dehydrogenase activity decreased after significantly after two- and fou-week Pb500 treatments. Wyszkowska et al. (2006) observed that the application of $50 \mathrm{mg} / \mathrm{kg} \mathrm{Pb}$ significantly reduced the dehydrogenase activity in soil.

Arylsulphatase plays is an indicator of sulphur mineralization in soil and is an important part in the cycling of this element (Lipińska et al. 2014). Its activity depends on several factors including heavy metals (Kang and Freeman 1999). However, we only found a positive correlation between this enzyme and the $\mathrm{Zn}$ concentration in the nonrhizosphere soils.

Additionally, in order to determine the relative toxicity of heavy metals to enzyme activity in the studied soils, we determined the enzyme activity change ratio (ACR). A positive ACR denotes that enzyme activity is enhanced and a negative ACR denotes that enzyme activity is reduced in the presence of heavy metals (Xian et al. 2015). In our study, a negative ACR primarily concerned urease and to a lesser extent the $\beta$-glucosidase activity. Gucwa-Przepióra et al. (2016) found a negative ACR in soil, which confirmed the inhibition of soil enzyme activity at a site that had been affected by smelting activity. Xian et al. (2015) indicated that for Cd- and As-polluted soils, the ACRs of the enzymes in the soils did not exhibit a consistent rise and fall pattern. 
In order to assess the total level of soil enzyme activity, we also calculated the integrated total enzyme activity index (TEI). The TEI was higher in the rhizosphere soil samples from all of the investigated sites, but we did not observe any differences between the sampling sites or correlations between the TEI and the studied soil properties. In contrast to our study, Tan et al. (2014) found positive correlations between the TEI and soil OM, total $\mathrm{N}$ and negative correlations between the soil pH values. Additionally, Fang et al. (2017) reported a positive correlation between the TEI and electrical conductivity.

In our study, individual enzyme activity had a stronger correlation with the soil physicochemical properties than the two indices: TEI and $M_{w}$ that were calculated.

\section{Biological indices}

This study was conducted at sites with different degrees of soil contamination and each of the investigated sites is described by a characteristic structure of soil microarthropod community. The soils from Miasteczko Śląskie (M) had the lowest number of microarthropod taxa as well as a low QBS and FEMI, which can be explained by the remarkably high concentrations of heavy metals at that site. Moreover, Santorufo et al. (2012) found a lower QBS in heavy-metal contaminated soils. Our results confirmed that heavy metals contamination affects QBS-ar values. In most cases the compared to the values obtained for human degraded soils e.g., from Poland, the UK, Sweden, and Italy where the other specialists obtained values of this biological indicator between 40 and 70 (Menta et al. 2018). This indicates that QBS and FEMI are quite sensitive to the habitat changes that are caused by the anthropogenic impact on soil. Similar results were found by Madej et al. (2011) and Menta et al. (2018). Pollution not only affects mesofauna by toxicity, but it can also cause some indirect effects through changes in the quantity and quality of the soil organic matter content and the associated microbial communities (Khalil et al. 2009). Many authors (Gwiazdowicz et al. 2006; Cui et al. 2016; Manu et al. 2017) have indicated a positive correlation between the number of microarthropods and the content of organic matter, TOC and $\mathrm{C} / \mathrm{N}$ in the soil. The higher content of the organic matter and the lower bioavailability of the heavy metals resulting from the presence of plants influence rhizosphere soil in a way that makes the living conditions for microarthropod better. That means that rhizosphere soil has a higher biological quality compared with non-rhizosphere soil. A higher number of microarthropods, as well as higher values of the QBS and FEMI indices, were found in the rhizosphere soil regardless on the degree of contamination on specific sites.

The soil fauna is a good tool to assess soil biological quality due to its complex nature. However, in this study, the
FEMI index seems to be a better indicator of the differences in soil quality both at the sites and the respective soil layers (i.e., the rhizosphere and non-rhizosphere soil). Because the FEMI considers both the presence and abundance of individual microarthropod taxa, it can assess soil quality more realistically than the QBS, which was confirmed in the results that were presented by Yan et al. (2012).

\section{Conclusions}

Based on the heavy metal content levels that were determined, their availability and their influence on soil enzyme activity and microarthropod communities in the Vaccinium myrtillus L. rhizosphere soil and the non-rhizosphere soil from sites with different degrees of pollution, the major findings of this study are as follows:

(1) The physicochemical and biological properties of the $V$. myrtillus rhizosphere soil was significantly different from those of the non-rhizosphere soil. Our results showed that the heavy metals had various patterns of mobility between the rhizosphere and non-rhizosphere soils at different polluted sites. The heavy metal bioavailability was generally higher in the rhizosphere soil samples except for the most polluted site-Miasteczko Śląskie. (2) In the V. myrtillus rhizosphere soil samples, enzyme activity was generally higher than in the non-rhizosphere soil. $\beta$-glucosidase and urease were strongly impacted by the organic matter content, the $\mathrm{C}$ and $\mathrm{N}$ levels and $\mathrm{pH}$ values. Moreover, these enzymes were most sensitive to $\mathrm{Cd}, \mathrm{Zn}$ and $\mathrm{Pb}$, which makes them good indicators for detecting the impact of heavy metal pollution in forest ecosystems. (3) The Vaccinium myrtillus L. rhizosphere soil had stronger correlation coefficient values between the measured parameters than the non-rhizosphere soil, which suggests that rhizosphere soil is more sensitive and could be used in the monitoring and assessment of forest ecosystems. (4) The QBS and FEMI methods, which are based on microarthropod communities, is a sensitive tool that can be used to assess the degree of soil degradation. Because of the conjunction between these methods and the soil physicochemical properties as well as level of contamination and other biological parameters such as soil enzyme activity, a proper assessment of soil quality is possible.

There is still a lack of knowledge on the impact of heavy metals on changes in the activity of soil enzymes and microarthropod communities in the rhizosphere of selected species growing in field conditions. The results that were obtained in our study cannot be interpreted in an unambiguous way and they only provide an indication of the effect of heavy metal contamination on the rhizosphere. However, this type of research, by identifying sensitive indicators, may help to improve the monitoring and assessment of forest ecosystems. 


\section{Data availability}

The data presented in this study are available on request from the corresponding author. The data are not publicly available due to privacy restrictions.

Acknowledgements The authors are grateful for the technical assistance of graduate student Romina Szala in the heavy metal and activity of soil enzymes estimations during the study.

Funding This research did not receive any specific grant from funding agencies in the public, commercial or not for profit sectors.

Author contributions Study concept and design: M.K.-C. Analysis and interpretation of data: M.K.-C., A.N.-S., G.B. Statistical analysis: M.K.-C., G.B. Drafting of the manuscript: M.K.-C. Critical revision of the manuscript for important intellectual content: A.N.-S., G.B.

\section{Compliance with ethical standards}

Conflict of interest The authors declare that they have no conflict of interest.

Consent to participate The authors declare that they have no known competing financial interests or personal relationships that could have appeared to influence the work reported in this paper.

Consent to publish Informed consent was obtained from all individual participants included in the study.

Ethical approval This article does not contain any studies with human participants or animals performed by any of the authors.

Informed consent Informed consent was obtained from all individual participants included in the study.

Publisher's note Springer Nature remains neutral with regard to jurisdictional claims in published maps and institutional affiliations.

Open Access This article is licensed under a Creative Commons Attribution 4.0 International License, which permits use, sharing, adaptation, distribution and reproduction in any medium or format, as long as you give appropriate credit to the original author(s) and the source, provide a link to the Creative Commons license, and indicate if changes were made. The images or other third party material in this article are included in the article's Creative Commons license, unless indicated otherwise in a credit line to the material. If material is not included in the article's Creative Commons license and your intended use is not permitted by statutory regulation or exceeds the permitted use, you will need to obtain permission directly from the copyright holder. To view a copy of this license, visit http://creativecommons. org/licenses/by/4.0/.

\section{References}

Acosta-Martinez V, Tabatabai MA (2000) Enzyme activities in a limed agricultural soil. Biol Fertil Soils 31:85-91. https://doi.org/10. 1007/s003740050628

Acosta-Martinez V, Zobeck TM, Gill TE, Kennedy AC (2003) Enzyme activities and microbial community structure in semiarid agricultural soils. Biol Fertil Soils 38:216-227. https://doi.org/10. 1007/s00374-003-0626-1

Angelovičová L, Lodenius M, Tulisalo E, Fazekašová D (2014) Effect of heavy metals on soil enzyme activity at different field conditions in middle Spis mining area (Slovakia). Bull Environ Contam Toxicol 93(6):670-675. https://doi.org/10.1007/s00128-014-1397-0

Aşkın T, Kızılkaya R (2006) Assessing spatial variability of soil enzyme activities in pasture topsoils using geostatistics. Eur J Soil Biol 42(4):230-237. https://doi.org/10.1016/j.ejsobi.2006.02.002

Aydinalp C, Katkat AV (2011) The comparison of extraction methods for evaluating some heavy metals in polluted soils Plant Soil Environ 50(5):212-2017

Baćmaga M, Kucharski J, Wyszkowska J, Tomkiel M, Borowik A (2015) Response of actinomycetes, phosphatases and urease to soil contamination with herbicides. Ecol Chem Eng S 22 (2):255-267. https://doi.org/10.1515/eces-2015-0015

Bartkowiak A, Lemanowicz J, Breza-Boruta B (2017) Evaluation of the content of $\mathrm{Zn}, \mathrm{Cu}, \mathrm{Ni}$ and $\mathrm{Pb}$ as well as the enzymatic activity of forest soils exposed to the effect of road traffic pollution. Environ Sci Pollut Res 24(30):23893-23902. https://doi.org/10. 1007/s11356-017-0013-3

Baudoin E, Benizri E, Guckert A (2002) Impact of growth stage on the bacterial community structure along maize roots, as determined by metabolic and genetic fingerprinting. Appl Soil Ecol 19 (2):135-145. https://doi.org/10.1016/S0929-1393(01)00185-8

Bhuiyan MA, Parvez L, Islam MA, Dampare SB, Suzuki S (2010) Heavy metal pollution of coal mine-affected agricultural soils in the northern part of Bangladesh. J Hazard Mater 173 (1-3):384-392. https://doi.org/10.1016/j.jhazmat.2009.08.085

Blakely JK, Neher DA, Spongberg AL (2002) Soil invertebrate and microbial communities, and decomposition as indicators of polycyclic aromatic hydrocarbon contamination. Appl Soil Ecol 21:71-88. https://doi.org/10.1016/S0929-1393(02)00023-9

Boamponsem LK, Adam JI, Dampare SB, Nyarko BJB, Essumang DK (2010) Assessment of atmospheric heavy metal deposition in the Tarkwa gold mining area of Ghana using epiphytic lichens. Nucl Instrum Methods B 268(9):1492-1501. https://doi.org/10.1016/j. nimb.2010.01.007

Boussen S, Soubrand M, Bril H, Ouerfelli K, Abdeljaouad S (2013) Transfer of lead, zinc and cadmium from mine tailings to wheat (Triticum aestivum) in carbonated Mediterranean (Northern Tunisia) soils. Geoderma 192:227-236. https://doi.org/10.1016/j. geoderma.2012.08.029

Cang L, Zhou DM, Wang QY, Wu DY (2009) Effect of electrokinetic treatment of a heavy metal contaminated soil on soil enzyme activities. J Hazard Mater 172:1602-1607. https://doi.org/10. 1016/j.jhazmat.2009.08.033

Chen Y, Wu P, Shao Y, Ying Y (2013) Health risk assessment of heavy metals in vegetables grown around battery production area. Sci Agric 71(2):126-132

Chróst RJ (1991) Environmental control of the synthesis and activity of aquatic microbial ectoenzymes. In: Chróst RJ (Ed.) Microbial enzymes in aquatic environments. Brock/Springer series in contemporary bioscience. Springer, New York, NY

Cui Y, Wang S, Yan S (2016) Evaluating the applicability of phi coefficient in indicating habitat preferences of forest soil fauna based on a single field study in subtropical China. PLoS ONE https://doi.org/10.1371/journal.pone.0150380.

Das SK, Varma A (2011) Role of enzymes in maintaining soil health. In: Shukula G, Varma A (eds) Soil enzymology. Springer-Verlag, Berlin Heidelberg, pp 25-42.

Deng W, Wang Y, Liu Z, Cheng H, Xue Y (2014) HemI: a toolkit for illustrating heatmaps. PLoS ONE 9(11):e111988. https://doi.org/ 10.1371/journal.pone.0111988

Effron D, De La Horra, Defrieri AM, Fontanive R, Palma PM (2004) Effect of cadmium, copper, and lead on different enzyme 
activities in a native forest soil. Comm Soil Sci Plant Anal 35:1309-1321. https://doi.org/10.1081/CSS-120037548

Egamberdieva D, Renella G, Wirth S, Islam R (2011) Enzyme activities in the rhizosphere of plants. In G Shukla, A Varma (Eds.), Soil enzymology. Soil biology, vol. 22, Springer Verlag, pp 149-165.

Fang L, Liu Y, Tian H, Chen H, Wang Y, Huang M (2017) Proper land use for heavy metal-polluted soil based on enzyme activity analysis around a $\mathrm{Pb}-\mathrm{Zn}$ mine in Feng County, China. Environ Sci Pollut Res 24(36):28152-28164. https://doi.org/10.1007/ s11356-017-0308-4

Feng MH, Shan XQ, Zhang SZ, Wen B (2005) Comparison of a rhizosphere-based method with other one-step extraction methods for assessing the bioavailability of soil metals to wheat. Chemosphere 59:939-949. https://doi.org/10.1016/j.chemosphere. 2004.11.056

Galli L, Capurro M, Menta C, Rellini I (2014) Is the QBS-ar index a good tool to detect the soil quality in Mediterranean areas? A cork tree Quercus suber L. (Fagaceae) wood as a case of study. Ital J Zoo 81 (1):126-135. https://doi.org/10.1080/11250003.2013.875601

Gao J (2010) Dynamic effects of PAEs on soil urease and phosphatase. Agricul Sci Technol 11(2):189-192

Garcia C, Roldan A, Hernandez T (2005) Ability of different plant species to promote microbiological processes in semiarid soil. Geoderma 124:193-202. https://doi.org/10.1016/j.geoderma. 2004.04.013

Ge Y, Zhang C, Jiang Y, Yue C, Jiang Q, Min H, Fan H, Zeng Q, Chang J (2011) Soil microbial abundances and enzyme activities in different rhizospheres in an integrated vertical flow constructed wetland. Clean 39(3):206-211. https://doi.org/10.1002/clen. 201000230

Gianfreda L (2015) Enzymes of importance to rhizosphere processes. J Soil Sci Plant Nut 15(2):283-306. https://doi.org/10.4067/S071895162015005000022

Gucwa-Przepióra E, Nadgórska-Socha A, Fojcik B, Chmura D (2016) Enzymatic activities and arbuscular mycorrhizal colonization of Plantago lanceolata and Plantago major in a soil root zone under heavy metal stress. Environ Sci Pollut Res 23:4742-4755. https:// doi.org/10.1007/s11356-015-5695-9

Gwiazdowicz DJ, Olszowska G, Robakowski P (2006) Preliminary research on Gamasid mite and the activity of selected soil enzymes in the Karkonosze National Park. Acta Sci Pol Silv Colendar Ratio Ind Lignar 5(2):51-61

Hassan W, Akmal M, Muhammad I, Younas M, Zahid KR, Ali F (2013) Response of soil microbial biomass and enzymes activity to cadmium $(\mathrm{Cd})$ toxicity under different soil textures and incubation times. AJCS 7(5):674-680

He ZL, Yang XE, Baligar VC, Calvert DV (2003) Microbiological and biochemical indexing systems for assessing acid soil quality. Adv Agron 78:89-138. https://doi.org/10.1016/S0065-2113(02)78003-6

Hinojosa MB, Carreira JA, Garcia-Ruiz R (2004) Microbiological rates and enzyme activities as indicators of functionality in soils affected by the Aznalcóllar toxic spill. Soil Biol Biochem 36:1637-1644. https://doi.org/10.1016/j.soilbio.2004.07.006

Hisinger P, Plassard C, Jaillard B (2006) Rhizosphere: a new frontier for soil biogeochemistry. J Geochem Explor 88(1-3):210-213. https://doi.org/10.1016/j.gexplo.2005.08.041

Hoffmann GG, Dedeken M (1966) Eine Methode zur colorimetrischen Bestimmung der $\beta$-Glucosidase-Aktivität in Böden. Zeitschrift für Pflanzenernährung, Düngung, Bodenkunde 108(3):193-198

Identification key (a): Mites and other arthropods: https://www. zoology.ubc.ca/ srivast/mites/index.html

Identification key (b): Soil microarthropods: ver.1.0 https://keyserver. lucidcentral.org/key-server/player.jsp?keyId $=56$

Insom E, La Terza A (2012) Applicazione del metodo QBS-ar per la valutazione della qualità biologica di suoli ammendati con
bokashi-Tesi Laurea triennale CL-32. https://doi.org/10.13140/ RG.2.1.3965.7124 (in Italy)

Jia Z, Li S, Wang L (2018) Assessment of soil heavy metals for ecoenvironment and human health in a rapidly urbanization area of the upper Yangtze. Basin. Sci Rep 8:3256. https://doi.org/10. 1038/s41598-018-21569-6

Jiao X, Teng Y, Zhan Y, Wu J, Lin X, Reigosa MJ (2015) Soil heavy metal pollution and risk assessment in Shenyang Industrial District, Northeast China. PloS ONE. https://doi.org/10.1371/journal. pone. 0127736

Jones DL, Hodge A, Kuzyakov Y (2004) Plant and mycorrhizal regulation of rhizodeposition. New Phytol 163(3):459-480. https:// doi.org/10.1111/j.1469-8137.2004.01130.x

Kandziora-Ciupa M, Nadgórska-Socha A, Barczyk G, Ciepał R (2017) Bioaccumulation of heavy metals and ecophysiological responses to heavy metal stress in selected populations of Vaccinium myrtillus L. and Vaccinium vitis-idaea L. Ecotoxicology 26 (7):966-980. https://doi.org/10.1007/s10646-017-1825-0

Kang H, Freeman C (1999) Phosphatase and arylsulphatase activities in wetland soils: annual variation and controlling factors. Soil Biol Biochem 31(3):449-454. https://doi.org/10.1016/S00380717(98)00150-3

Karaca A, Cetin SC, Turgay OC, Kizilkaya R (2010) Effects of heavy metals on soil enzyme activities. In: Sherameti I, Varma A, (Eds.) Soil heavy metals. Soil biology 19. Springer-Verlag, Berlin Heidelberg, pp 237-262.

Khalil AM, Janssens KS, Berg MP, van Straalen NM (2009) Identification of metal-responsive oribatid mites in a comparative survey of polluted soils. Pedobiologia 52:207-221. https://doi.org/ 10.1016/j.pedobi.2008.10.002

Khan S, Cao Q, Hesham AEL, Xia Y, He JZ (2007) Soil enzymatic activities and microbial community structure with different application rates of $\mathrm{Cd}$ and $\mathrm{Pb}$. J Environ Sci 19(7):834-840. https://doi.org/10.1016/S1001-0742(07)60139-9

Li YT, Rouland C, Benedetti M, Li FB, Pando A, Lavelle P, Dai J (2009) Microbial biomass, enzyme, and mineralization activity in relation to soil organic $\mathrm{C}, \mathrm{N}$ and $\mathrm{P}$ turnover influenced by acid metal stress. Soil Biol Biochem 41(5):969-977. https://doi.org/ 10.1016/j.soilbio.2009.01.021

Lipińska A, Kucharski J, Wyszkowska J (2014) Activity of arylsulphatase in soil contaminated with polycyclic aromatic hydrocarbons. Water Air Soil Pollut 225(9):2097. https://doi.org/10. 1007/s11270-014-2097-4

Liu G, Tao L, Liu X, Hou J, Wang A, Li R (2013) Heavy metal speciation and pollution of agricultural soils along Jishui River in non-ferrous metal mine area in Jiangxi Province, China. J Geochem Explor 132:156-163. https://doi.org/10.1016/j.gexplo. 2013.06.017

Liu Y, Liu S, Liu D, Wei Y, Liu C, Yang Y, Tao C, Liu W (2014) Exploiting EST databases for the development and characterization of EST-SSR markers in blueberry (Vaccinium) and their cross-species transferability in Vaccinium spp. Sci Hortic 176:319-329. https://doi.org/10.1016/j.scienta.2014.07.026

Luo Q, Wang S, Sun L, Wang H (2017) Metabolic profiling of root exudates from two ecotypes of Sedum alfredii treated with $\mathrm{Pb}$ based on GC-MS. Sci Rep 7:39878. https://doi.org/10.1038/ srep39878

Madej G, Barczyk G, Gdawiec M (2011) Evaluation of soil biological quality index (QBS-ar): its sensivity and usefulness in the postmining chronosequence-preliminary research. Pol J Environ Stud 5:1367-1372. https://doi.org/10.15244/pjoes/64743

Manu M, Băncilă RI, Iordache V, Bodescu F, Onete M (2017) Impact assesment of heavy metal pollution on soil mite communities (Acari: Mesostigmata) from Zlatna depression-Transylvania. Process Saf Environ 108:121-134. https://doi.org/10.1016/j.psep. 2016.06.011 
Matuszkiewicz JM, Kowalska A, Solon J, Degórski M, Kozłowska A, Roo-Zielińska E, Zawiska I, Wolski J (2013) Long-term evolution models of post-agricultural forests. PAN, Warszawa.

Mazurek R, Kowalska JB, Gąsiorek M, Zadrożny P, Józefowska A, Zaleski T, Kępka W, Tymczuk M, Orłowska K (2017) Assessment of heavy metals contamination in surface layers of Roztocze National Park forest soils (SE Poland) by indices of pollution. Chemosphere 168:839-850. https://doi.org/10.1016/j.chemosphere. 2016.10.126

Menta C, Conti FD, Pinto S, Bodini A (2018) Soil biological quality index (QBS- ar): 15 years of application at global scale. Ecol Indic 85:773-780. https://doi.org/10.1016/j.ecolind.2017.11.030

Menzies NW, Donn MJ, Kopittke PM (2007) Evaluation of extractants for estimation of the phytoavailable trace metals in soils. Environ Pollut 145(1):121-130. https://doi.org/10.1016/j.envpol.2006.03.021

Mmolawa KB, Likuku AS, Gaboutloeloe GK (2011) Assessment of heavy metal pollution in soils along major roadside areas in Botswana. Afr J Environ Sci Technol 5(3):186-196

Müehlbachová G, Simon T, Pechova M (2005) The availability of Cd, $\mathrm{Pb}$ and $\mathrm{Zn}$ and their relationships with soil $\mathrm{pH}$ and microbial biomass in soils amended by natural clinoptilolite. Plant Soil and Environ 51:26-33

Muller G (1969) Index of geoaccumulation in sediments of the Rine River Geo. J. 2:108-118

Nannipieri P, Kandeler E, Ruggiero P (2002) Enzyme activities and microbiological and biochemical processes in soil In: Burns RG, Dick RP (eds) Enzymes in the environment: activity, ecology and applications. Marcel Dekker, New York, pp 1-33

Narendrula-Kotha R, Nkongolo KK (2017) Changes in enzymatic activities in metal contaminated and reclaimed lands in Northern Ontario (Canada). Ecotox Environ Saf 140:241-248. https://doi. org/10.1016/j.ecoenv.2017.02.040

Navarrete IA, Gabiana CC, Dumo JR, Salmo SG, Guzman MA, Valera NS, Espiritu Q (2017) Heavy metal concentrations in soils and vegetation in urban areas of Quezon City, Philippines. Environ Monit Assess 189:145. https://doi.org/10.1007/s10661-017-5849-y

Olaniran AO, Balgobind A, Pillay B (2013) Bioavailability of heavy metals in soil: impact on microbial biodegradation of organic compounds and possible improvement strategies. Int J Mol Sci 14 (5):10197-10228. https://doi.org/10.3390/ijms140510197

Orroño DI, Schindler V, Lavado RS (2012) Heavy metal availability in Pelargonium hortorum rhizosphere: interactions, uptake, and plant accumulation. J Plant Nutr 35(9):1374-1386. https://doi. org/10.1080/01904167.2012.684129

Ostrowska A, Gawliński S, Szczubiałka Z (1991) Methods of analysis and evaluation of soil and plant properties. Catalog. Institute of Environ Protect, Warsaw.

Pan F, Zhang W, Liang Y, Liu S, Wang K (2018) Increased associated effects of topography and litter and soil nutrients on soil enzyme activities and microbial biomass along vegetation successions in karst ecosystem, southwestern China. Environ Sci Pollut Res 25 (17):16979-16990. https://doi.org/10.1007/s11356-018-1673-3

Pan J, Yu L (2011) Effects of Cd or/and Pb on soil enzyme activities and microbial community structure. Ecol Eng 37(11):1889-1894. https://doi.org/10.1016/j.ecoleng.2011.07.002

Paoletti MG (Ed.) (1999) Invertebrate biodiversity as bioindicators of sustainable landscapes. Practical use of invertebrates to assess sustainable landuse. Elsevier, p 446.

Parissi V, Menta C, Gardi C, Jacomini C, Mozzanica E (2005) Microarthropod communities as tool to assess soil quality and biodiversity: a new approach in Italy. Agri Ecosyst Environ 105:323-333. https://doi.org/10.1016/j.agee.2004.02.002

Parisi V, Menta C (2008) Microarthropods of the soil: convergence phenomena and evaluation of soil quality using QBS-ar and QBS-C. Fresenius Environ Bull, 17:1170-1174
Patel A, Patra DD (2014) Influence of heavy metal rich tannery sludge on soil enzymes vis-à-vis growth of Tagetes minuta, an essential oil-bearing crop. Chemosphere 112:323-332. https://doi.org/10. 1016/j.chemosphere.2014.04.063

Pattnaik BK, Equeenuddin SM (2016) Potentially toxic metal contamination and enzyme activities in soil around chromite mines at Sukinda Ultramafic Complex, India. J Geochem Explor 168:127-136. https://doi.org/10.1016/j.gexplo.2016.06.011

Pennesi R, Insom E (2012) Applicazione del metodo QBS-ar per la valutazione della qualità biologica di suoli ammendati con bokashi-Tesi Laurea triennale CL-32. Università degli Studi di Camerino, supervised-student-publication. https://doi.org/10. 13140/RG.2.1.3965.7124

Rao MA, Scelza R, Gianfreda L (2014) Soil enzymes. In: Gianfreda L, Rao MA (eds) Enzymes in agricultural sciences. OMICS Group, Foster City, pp 1-18

Santorufo L, Van Gestel CAM, Rocco A, Maistoa G (2012) Soil invertebrates as bioindicators of urban soil quality. Environ Pollut 161:57-63. https://doi.org/10.1016/j.envpol.2011.09.042

Schinner F, Öhlinger R, Kandeler E, Margesin R (1996) Methods in Soil Biology. Springer, Berlin

Strobl W, Traunmüller M, Kandeler E (1996) Enzymes Involved in Sulfur Metabolism. In: Schinner F, Öhlinger R, Kandeler E, Margesin R (eds) Methods in Soil Biology. Springer, Berlin, Heidelberg. https://doi.org/10.1007/978-3-642-60966-4_14

Stork NE, Eggleton P (1992) Invertebrates as determinants and indicators of soil quality. Am J Altern Agric 7(1-2):38-47

Szarek-Łukaszewska G, Niklińska M (2002) Concentration of alkaline and heavy metals in Biscutella laevigata L. and Plantago lanceolata L. growing on calamine spoils (S. Poland). Acta Biol Cracov Ser Bot 44:29-38

Tabatabai MA, Bremner JM (1969) Use of p-nitrophenyl phosphate for assay of soil phosphatase activity Soil Biol Biochem 1(4):301-307

Tabatabai MA, Bremner JM (1970) Arylsulfatase Activity of Soils Soil Science Society of America Journal 34(2):225-229

Tan X, Xie B, Wang J, He W, Wang X, Wei G (2014) County-scale spatial distribution of soil enzyme activities and enzyme activity indices in agricultural land: implications for soil quality assessment. Sci World J https://doi.org/10.1155/2014/535768

Minister of the Environment (2002) The regulation of Environment Minister about standards of soil and ground quality, The Act Gazette of Poland no 165 pos. 1358 and 1359 from 09.09.2002

Trasar-Cepeda C, Leirós MC, Gil-Sotres F (2008) Hydrolytic enzyme activities in agricultural and forest soils. Some implications for their use as indicators of soil quality. Soil Biol Biochem 40:2146-2155. https://doi.org/10.1016/j.soilbio.2008.03.015

Turner BL (2010) Variation in $\mathrm{pH}$ optima of hydrolytic enzyme activities in tropical rain forest soils. Appl Environ Microb 76 (19):6485-6493

Turner BL, Hopkins DW, Haygarth PM, Ostle N (2002) $\beta$-Glucosidase activity in pasture soils. Appl Soil Ecol 20(2):157-162. https:// doi.org/10.1016/S0929-1393(02)00020-3

Vig K, Megharaj M, Sethunathan N, Naidu R (2003) Bioavailability and toxicity of cadmium to microorganisms and their activities in soil: a review. Adv Environ Res 8(1):121-135. https://doi.org/10. 1016/S1093-0191(02)00135-1

Wahsha M, Nadimi-Goki M, Fornasier F, Al-Jawasreh R, Hussein EI, Bini C (2017) Microbial enzymes as an early warning management tool for monitoring mining site soils. Catena 148:40-45. https://doi.org/10.1016/j.catena.2016.02.021

Wang J, Zhang CB, Jin ZX (2009) The distribution and phytoavailability of heavy metal fractions in rhizosphere soils of Paulowniu fortunei (seem) Hems near a $\mathrm{Pb} / \mathrm{Zn}$ smelter in Guangdong, PR China. Geoderma 148(3-4):299-306. https://doi.org/10.1016/j. geoderma.2008.10.015 
Wang Z, Shan XQ, Zhang S (2002) Comparison between fractionation and bioavailability of trace elements in rhizosphere and bulk soils. Chemosphere 46(8):1163-1171. https://doi.org/10.1016/ S0045-6535(01)00206-5

Wójcik M, Sugier P, Siebielec G (2014) Metal accumulation strategies in plants spontaneously inhabiting $\mathrm{Zn}-\mathrm{Pb}$ waste deposits. Sci Total Environ 487:313-322. https://doi.org/10.1016/j.scitotenv.2014.04.024

Wyszkowska J, Kucharski J, Lajszner W (2006) The effects of copper on soil biochemical properties and its interaction with other heavy metals. Pol J Environ Stud 15(6):927-934

Wyszkowska J, Wyszkowski M (2003) Effect of cadmium and magnesium on enzymatic activity in soil. Pol J Environ Stud 12(4):473-479

Xian Y, Wang M, Chen W (2015) Quantitative assessment on soil enzyme activities of heavy metal contaminated soils with various soil properties. Chemosphere 139:604-608. https://doi.org/10. 1016/j.chemosphere.2014.12.060

Xiao S, You H, You W, Liu J, Cai C, Wu J, He D (2017) Rhizosphere and bulk soil enzyme activities in a Nothotsuga longibracteata forest in the Tianbaoyan National Nature Reserve, Fujian Province, China. J For Res 28(3):521-528. https://doi.org/10.1007/ s11676-016-0334-y

Yan A, Singh AN, Fu S, Liao CH, Wang S, Li Y, Cui Y, Hu L (2012) A soil fauna index for assessing soil quality. Soil Biol Biochem 47:158-165. https://doi.org/10.1016/j.soilbio.2011.11.014
Yan S, Singh AN, Fu S, Liao CH, Wang S, Li Y, Cui Y, Hu L (2012) A soil fauna index for assessing soil quality Soil Biol and Biochem 47:158-165

Yang J, Yang F, Yang Y, Xing G, Deng C, Shen Y, Yuan H (2016) A proposal of "core enzyme" bioindicator in long-term $\mathrm{Pb}-\mathrm{Zn}$ ore pollution areas based on topsoil property analysis. Environ Pollut 213:760-769. https://doi.org/10.1016/j.envpol.2016.03.030

Yang Y, Dong M, Cao Y, Wang J, Tang M, Ban Y (2017) Comparisons of soil properties, enzyme activities and microbial communities in heavy metal contaminated bulk and rhizosphere soils of robinia pseudoacacia L. in the Northern foot of Qinling Mountain. Forests 8(11):430. https://doi.org/10.3390/f8110430

Youssef RA (1997) Studies on nickel and manganese dynamic in the rhizosphere of wheat. Plant nutrition for sustainable food production and environment. Springer, Dordrecht, pp 483-486

Zhang Y, Zhang H, Su Z, Zhang C (2008) Soil microbial characteristics under long-term heavy metal stress: a case study in Zhangshi wastewater irrigation area, Shengyang. Pedosphere. 18:1-10. https://doi.org/10.1016/S1002-0160(07)60097-6

Zheljazkov VD, Jeliazkova EA, Kovacheva N, Dzhurmanski A (2008) Metal uptake by medicinal plant species grown in soils contaminated by a smelter. Environ Exp Bot 64(3):207-216. https:// doi.org/10.1016/j.envexpbot.2008.07.003 